\title{
Political Idea Movements and Intellectual Changes in the History Curricula
} (1908-1930)

\section{Tuba ŞENGÜL ${ }^{*}$}

\begin{abstract}
Every government wants to provide education and teaching for new generation according to its own ideology. Education, especially history education, has important mission to find out these thought and take root of these thought. The changing of society has affected aspects in education, politics and social. However, the science of history has crucial role in order to bring up persons who appreciate the ideology of the administration of a country.

In this study, we are researched into the aim of attract attention for intellectual changes between the years 1908-1930 and how political idea movements a role-played and affected on determination of secondary history curricula? How these events were transferred to history lesson curriculum was also studied. The study examined many sources, domestic and foreign sources, on pre-republic and post-republic documents such as books, journals, curriculum document and textbook. The Turkish History Thesis and then were not included in this study.
\end{abstract}

\footnotetext{
* Research Assistant; Gazi University, Gazi Faculty of Education, Department of Secondary Education Social Studies Teaching, History Teaching programme/ ANKARA.
} 
The historical methodology, which includes study archive searching and review of literature, was used as a research method. The methodology also includes extensive library research whereby the researchers studied the archives on available materials on the subject matter.

Key Words: History Education, History Teaching, Political Idea Movements, Intermediate Education.

\section{SUMMARY}

Every government stresses the importance of education and instruction for the new generation according to its belief. The government holds firm to its ideology and wants uphold it. History education especially has a very important function to play in order to uphold the ideology and stand by it. Changing society has affected political and social lives as well education development. However, the science of history has crucial influence on persons who deal with administration of a country's ideology.

In this study, how political idea movements were a role-played and affected on determination of secondary history curricula that we are researched into the aim of attract attention for intellectual changes between the years 1908-1930. The study examined many sources of documents, domestic and foreign sources, such as books, journals, curriculum and textbook. With this aim, the historical methodology, which includes study archive searching, was used as a research method. Data were collected through three methods: firstly library research whereby historical archive was studied extensively. Secondly, data was collected through studying various government documents pertaining to the subject matter. Notes were recorded after the sourced were studied rigorously. Finally, data was collected through information-gathering method whereby sources related to the main titles had been collected and classified before the necessary looking at the course programs and history course curriculum programs used in secondary education between the years 1908 and 1930. After that, data were gathered, processed and evaluated. Also, Ideal movement which created intellectual changes in the term of curricula and history textbook were examined. It was found that effectiveness of history education and instruction of history on the society played an important role and were greatly considered.

Activity of political idea movements were seen on history curricula at between 1908-1930. In this term history education was effected in terms 
ideology which was encouraged by the authority. Lessons of history and the instructions were seen as a method more than an aim. This situation has been going on even in recent times because publishers of history textbooks comply with authority and the curriculum. But this kind of conformity has digressed from the objective of the new generation who has different ideas and thinking. These changes bring about growing consciousness of students when it comes to their history. We tried to focus on importance of history lesson based on what happened in the past. 


\title{
Siyasi Düşünce Akımları ve Tarih Ders Programlarındaki Düşünsel Değişim (1908-1930)
}

\author{
Tuba ŞENGÜL*
}

ÖZ: Her iktidar, yeni nesle kendi savunduğu ideolojisine yönelik bir eğitim ve öğretim vermek, ona kendi damgasını vurmak ister. Böyle bir düşüncenin uyanmasında, beslenip kökleşmesinde eğitim, özellikle de tarih eğitimi önemli bir görev üstlenmektedir. Toplumun düşünce hayatındaki değişimler, siyasi ve sosyal hayat üzerinde etkili olduğu gibi eğitim hayatı üzerinde de etkili olmuştur. Tarih bilimi ise, bir ülke yönetiminin düşünce yapısına uygun bireyler yetiştirmek yolunda önemli bir yere sahiptir.

Araştırmada, tarih programlarındaki düşünsel değişimlere dikkat çekmek amacıyla 1908-1930 yılları arasında siyasi düşünce akımlarının ortaöğretim tarih ders programlarının belirlenmesinde nasıl bir rol oynadığı ve etkinliğinin ne olduğu araştırılmıştır. Çalışma, cumhuriyet öncesi ve sonrası, kitap, süreli yayın, program ve ders kitabı gibi çok sayıda yerli ve yabancı kaynağın incelemesini kapsamaktadır. Araştırma kapsamına Türk Tarih Tezi ve sonrası alınmamıştır. Araştırma yöntemi olarak tarama modellerinden, literatür incelemesi ve arşiv taramasını içeren tarihi yöntem kullanılmıştır. Veriler belgesel taramanın genel tarama şekline yönelik olarak toplanmış, içeriğe yönelik bir çözümleme yapılmamıştır.

Anahtar Sözcükler: Tarih Eğitimi, Tarih Öğretimi, Siyasi Düşünce Akımları, Ortaöğretim.

\footnotetext{
* Araştırma Görevlisi; Gazi Üniversitesi Eğitim Fakültesi, Ortaöğretim Sosyal Alanlar Eğitimi Bölümü Tarih Eğitimi Ana Bilim Dalı Öğretim Elemanı /ANKARA.
} 


\section{Gİiș}

Eğitim kişinin zihnî, bedenî, duygusal ve toplumsal yetenekleri ile davranışlarının istenilen doğrultuda geliştirilmesi ya da ona bir takım amaçlara dönük yeni yetenekler, davranışlar kazandırılması yolundaki çalışmaların tümü olarak tanımlanabilir (Akyüz, 2001:2). Ama bu tanım tek değildir. Eğitimin tanımını pek çok araştırmacı farklı şekillerde yapmıştır. Fidan (1986:6), eğitim insanları belli amaçlara göre yetiştirme sürecidir derken, Doğan (2005:84), yetişkinlerin yetişmekte olan kuşakları toplumsal hayata hazırlama, aynı zamanda da bir kültür aktarma süreci olarak eğitimi tanımlamaktadır. Kafadar (1997:63) ise, "sosyal yapının dinamikliği özelliğinden dolayı, eğitim toplumun sosyal, kültürel, ekonomik ve siyasi yapısındaki değişmelerin lokomotifi olmaktadır" demektedir.

Toplumun sağlıklı adımlar atması ve her bireyi mutlu kılacak kuralların uygulanması eğitimle gerçekleșir. Eğitim, toplumların bilinçlenmesinde önemli bir unsur olarak görülmüş ve özellikle tarih eğitimi bu konuda öncü bir rol oynamıştır (Şengül, 2005:131). Toplumsal ve ulusal bilinçlenme açısından önemli bir yere sahip olan tarih eğitimi, günün ve dönemin şartlarına uygun olarak siyasi, sosyal hayattan ve düşünsel yapıdan etkilenmiş, program ve ders kitap içeriklerine de bu durumun etkileri yansımıştır.

19. yüzyılda Osmanlı Devleti'ni, içinde bulunduğu sıkıntılardan kurtarmak için dönemin aydınları bazı düşünsel tartışmalar içine girmişler ve bu yüzyılda "Bu devlet nasıl kurtulur?" sorusuna yanıt aramışlardır. $\mathrm{Bu}$ soruya Osmanlı aydınları, farklı yollarla yanıt bulmaya çalışmışlar, bu farklılıklar düşünce akımlarını doğurmuştur. Farklı düşünce akımları aydınlar tarafından bir yol gösterici olarak görülmüş ve ülke politikasını yönlendirici, siyasi bir hale getirilmiştir. Bunlar; "Batıcılık", "Osmanlıcılık", "İslâmcılık" ve "Türkçülük" akımlarıdır. Bu akımlar, dönem dönem etkinliklerini arttırmaları ile sadece siyasi yapıya etki etmekle kalmamışlar, sosyal yapıya ve özellikle eğitim alanına da yansımalarda bulunmuşlardır.

Siyasal sistemler, ihtiyaç duydukları siyasi, ideolojik ve ekonomik nitelikli güçleri toplumsal-siyasal kurumlar aracılığı ile sağlarlar. Bu süreçte eğitim, devlete belirtilen güçleri sağlayan önemli bir kurum olarak karşımıza çıkar (Akçay, 2006:28). Eğitim topluma yön vermede etkili bir yönlendirici olarak görülmektedir.

Meşrutiyet'ten Cumhuriyet'e geçişin olduğu 1908-1930 yılları arasında ortaöğretim kurumlarında okutulan tarih dersi programlarının yardımı ile düşünsel yapıya destek sağlayacak gelecek nesiller yetiştirilmeye çalışılmışıır. İktidarların eğilimlerine yönelik hazırlanan programlar 
öğretimde kullanılmış ve bu şekilde birlik-bütünlük sağlanması amaçlanmıştır.

Araştırma için özellikle ortaöğretim kurumları seçilmiştir. Bunun temel nedeni, tarih dersinin temelini oluşturan ve soyut bir kavram olan zaman olgusunun iyice anlaşılması sonucu verilebilecek bir ders olmasıdır. Ayrıca tarih dersi ile belli bir ideolojinin verilebilmesi, öğrencilerin olgunluk düzeylerinin gelişimine bağlıdır.

Bu nedenle; tarih programlarındaki düşünsel değişimlere dikkat çekmek amacıyla 1908-1930 yılları arasında siyasi düşünce akımlarının ortaöğretim tarih ders programlarının belirlenmesinde nasıl bir rol oynadığı ve etkinliğinin ne olduğu araştırılmıştır. Ortaöğretim kurumu olarak da; idadiler, sultaniler ve liseler ele alınmıştır.

Bugünün tarih eğitim yapısının anlaşılabilmesi için; 1908-1930 dönemi tarih eğitim yapısının incelenmesi önemlidir. $\mathrm{Bu}$ durum, tarih eğitimi yolunda aşılan mesafeyi görmemiz açısından da öneme sahiptir.

Çalışma, literatüre dayalı olarak cumhuriyet öncesi ve sonrası, kitap, süreli yayın, program, ders kitabı gibi çok sayıdan yerli ve yabancı kaynağın incelemesini kapsamakta ve daha önce dikkat çekilmeyen bir konuya dikkat çekmektedir.

\section{SIYYASİ DÜŞÜNCE AKIMLARI}

1908 y1lı ile başlayan II. Meşrutiyet dönemi, Osmanlı'nın son zamanlarına rastlar. Bu dönem imparatorluktan milli devlete geçiş dönemi olarak adlandırılabileceği gibi, Osmanlı'nın tasfiyesi ile Cumhuriyet'in yapılanmasını hazırlayan bir dönem olarak da görülebilir. Düşünce akımlarının incelenmesi açısından ise, bu dönem bir laboratuardır.

18. Yüzy1ldan itibaren, Osmanlı Devleti'nin içinde bulunduğu siyasi ve sosyal sıkıntılar onu yıkılmanın eşiğine getirmiştir. Avrupa'da meydana gelen olaylarla, etnik gruplarda ulus bilinci gelişmiş ve bu durum çok uluslu bir yapıya sahip olan Osmanlı Devleti'nde kargaşaya neden olmuştur. $\mathrm{Bu}$ gelişmeler karşısında Osmanlı aydınları "Bu Devlet Nasıl Kurtulur?" sorusunu gündeme getirerek, bu soruna nasıl bir uygulama ile çözüm getirebileceklerini düşünmüşler ve konuya dair düşünsel teoriler üretmişlerdir. İşte bu teoriler, tarihi platformda siyasi düşünce akımları olarak anılmaktadır. Araştırma kapsamında Batıcılık, Osmanlıcılık, İslâmcılık ve Türkçülük akımları ele alınmıştır. Bu akımlardan kısa kısa söz etmenin yeterli olacağ 1 kanaatindeyiz. 
Osmanlı Devleti duraklama döneminde, Kanuni Sultan Süleyman dönemi kurumlarının bozulmasından ve yozlaşmasından kaynaklanan ciddi sıkıntılar yaşamış, bu durumu ıslah edebilmek için, Genç Osman, Kuyucu Murat Paşa, IV. Murat ve Köprülüler tarafından yürütülen çalışmalar sonuçsuz kalmıştır. Aydınlanma Çağı, Sanayi Devrimi ve Fransız Devrimi... gibi insanlığın gelişiminde çok önemli sayılabilecek adımları atan Avrupa, kısa sürede üstün teknoloji sahibi modern orduları ve güçlü endüstrileri kurarak büyük bir gelişme göstermiştir. Batı ile arasındaki seviyenin giderek açıldığını gören Osmanlı devlet adamları, askeri teknolojiyi bilen ve kullanabilen "Fen Subayları" yetiştirebilmek için, Askeri Mühendislik Okulları kurmuşlardır (İnalcık 1992:623). Yabancı dil öğreniminin, bilimin ve teknolojinin transferindeki yeri ve önemi anlaşlıp bu yönde çalışmalar başlatılmıştır. Bu gelişmelerin 1şı̆̆ında III. Selim, devleti çöküntüden kurtarabilmek için sadece modern bir ordu kurmanın yeterli olamayacağını görerek yeni bir devlet düzeni aramaya yönelmişse de başarı sağlayamamıştır. Ancak II. Mahmut, yenileşme hareketlerini köstekleyen Yeniçeri Ocağını 1826'da kaldırarak yenileşme yolunu açmıştır. Kurulan yeni ordu, onu destekleyecek öğretim kurumlarını gerektirmiş, bu itibarla 1827'de Tibbiye ve 1834 'te Harbiye açılmıştır. Bu tarihlerden sonra, askeri okullardan mezun olanlar, Türk toplumunun çağdaşlaşmasına öncülük etmişler, özellikle Harbiye, halk ile idarenin bütünleşmesinde önemli roller oynamıştır (Özgüldür 2006:9). Bu aşamalarla gerçekleşen batılılaşma hareketleri, II. Meşrutiyet sonrasında ise, "Batıcılık" düşüncesi olarak, daha da etkili bir şekilde, siyasi ve düşünsel yönü ile toplumda kendini hissettirmiştir. Batılılaşma uzun bir süre askeri alanda kendini göstermiş, bu düşüncenin temellenmesinde Osmanlı'nın yenik duruma düşmesi ve Batı uygarlığının büyük bir gelişme göstermesinin etkisi büyük olmuştur. Bazı aydınların, iyisiyle kötüsüyle Batı'nın her şeyinin alınması gerektiği konusundaki söylemleri ise, bu fikrin temellini oluşturmuştur.

II. Abdülhamit döneminde de yenileşme hareketleri sürmüştür. Bu dönemde, çağdaşlaşma sorunu basit bir sorundur. Batı uygarlığından alınacak şeyler ancak 'faydalı' olan yanlardır. Padişah da yönetim de, Batı etkisinin olumsuz ve zarar verici olduğu düşünmesine rağmen, modern eğitim kurumlarının kurulması konusuna ağıllık vermiş, daha çok diğer alanlarda gelenekselciliği koruma politikası izlenmiştir. Ancak modern eğitim kurumlarının açılması ve yaygınlaşması üzerine, çağdaş bilgilerin yayılmasıyla Batılılaşma taraftarları da çoğalmıştır. Batılılaşma konusunda olumlu ve olumsuz pek çok yorumlar yapılmıştır. Hatta Batıcılar kendi aralarında dahi bazı ayrılıklara gitmişlerdir. 
Batıcılar, Celal Nuri ve Abdullah Cevdet'in batılllaşma görüşleri çevresinde iki gruba ayrılmışlardır. Bunlardan Celal Nuri gibi düşünenlere Kısmi Batıcılar, Abdullah Cevdet ile aynı düşünceleri taşıyanlara da Tam(Bütüncü) Batıcılar adı verilmiştir. Tam Batıcılar 'İçtihad' dergisi çerçevesinde düşüncelerini yaymaya çalışırlarken, Kısmi Batıcılar ise, 'Serbest Fikir' dergisi aracılığı ile görüşlerini kamuoyu ile paylaşmışlardır. Tam Batıcılara yani Bütüncülere göre, Batı medeniyeti bir bütündür. Ancak bütünlüğü ile alınabilir, bu kesin bir karardır. Türkiye Cumhuriyeti'nin kuruluşundan bu yana, genel olarak kabul edilmiş bir prensiptir. Bu prensipte birleşenlerin müşterek olarak işledikleri temalar vardır. Bunların büyük bir kısmında aralarındaki görüş birliği gayet açık olarak görülmektedir. Ayrıldıkları noktalar Batılılaşmayı gerçekleştirme yolları hakkında ayrıntı sayılabilecek noktalardır. Kısmi Batıcılara göre ise, Batı tamamen alınamaz. Kısmen alınabilir. Bölünerek alınabilir. Batı'dan alınacak olan kısım da onun tekniğidir (Tunaya, 2004:129,130,146).

Dönemin aydınlarından Prens Sabahattin, bütüncülük ve bireycilik ayrımının yapıldığı bir durumda karşımıza çıkar. O, "Devlet nasıl kurtulur?" sorusuna cevap olarak öncelikle bireyci bir toplum olmaya yönelmek gerektiğini göstermiştir. Doğu'nun tümüyle bütüncü yapının, Batı'nın ise özellikle bireyci yapının etkisinde olduğunu, yapılacak yenileştirme faaliyetlerinin başarılı olabilmesi için de bütüncü yapıdan bireyci yapıya geçilmesi gerektiğini söylemektedir. "Ancak bu demek, Batılılaşmak demek değildir" diyen Prens Sabahattin düşüncelerini şu şekilde açılamıştır $(1965: 42,43,44)$ :

“...Ama bireyci yapı doğrultusunda yürümek batılılaşmak değildir. Çünkü batıda da bireyciliğin etkisi üstün bulunmakla birlikte, iki büyük yapı, kendilerinden ayrılan dallarla birlikte karşı karşıya gelmiş ve Avrupa'nın çeşitli ülkeleri de karışmış bir halde bulunuyor. $\mathrm{Bu}$ durumda gelişi güzel batılılaşmak gereksiniminden söz açmak bir kez, sorunu en yüzeyden bir bakışla görmektir... Hiçbir milleti taklide çalışmakla o millet olamayacağımız ve doğrusu, olmamızda pek istenen bir şey olmayacağı gibi yalnız milliyetimize sarılmakla da olduğumuzdan fazla bir varlığa sahip olamayız. Çünkü en etkin bir ekonomik ve tarımsal bayındırlaşmanın doğurduğu sosyal yetenek ve bu yeteneği gittikçe geliştiren bir terbiye-i infiradiye ile kazanılacak sonuç, hiçbir zaman duygularla ve dileklerle sağlanamaz... Ama aydın çevremizde batılılaşma fikri, ülkemizi batının 'maddi' ve 'manevi' araçlarıyla donatmak anlamına alınıyor ve sanıyoruz ki en gelişmiş ülkelerde olduğu gibi Türkiye'de de şoseler, demiryolları...vb. gibi tesisler meydana getirecek olursak Türkiye’yi Batının uygarlık düzeyine yükseltebiliriz. Hiç düşünmüyoruz ki, biz bunlardan hep yoksun olagelmişken, batı bunları çoktan çıkarmış ve 
çıkarmakta devam ediyor. Doğunun geriliği; yol'suzluk ya da bilgisizlik veya yönetim aksaklığından ileri geliyor deyivermekle, nasıl duraklama ve gerileme nedenlerimiz açıklanmış olmuyorsa; batının bugünkü gelişmesi, yolları, okulları, bilim kurumlarının yetkinliğinden ya da hükümetlerinin iyi yönetiminden doğuyor demekle de oranın üstünlük nedenleri açıklanmış olunmuyor."

Batılılaşma yolunda, batının sadece çağdaş uygarlık araçlarını almayı yeterli görenlere Prens Sabahattin bir uyarıda bulunmaktadır (1965:44). O,

"Unutmayalım ki ülkemizi çăgdaş uygarlık araçlarıyla donatabilmek için yine batının mali yardımına başvurmak zorundayız. Bu başvurma, bugünkü sosyal koşullarımız altında, ister istemez yönetim erki yoluyla olacağından, yönetim hayatının, özel hayat üzerinde baskı ve zorbalığ daha da artacak. Yani bu konuda yapılacak girişimlerin, meydana getirilecek kurumların biricik etken ve sahibi görünüşte hükümet, temeldeyse batı olacak."

şeklindeki yorumuyla uyarısını tekrarlamaktadır.

Batı ve Batılılaşma konusunda Hilmi Ziya Ülken de yorumlar yapmıştır. Bu konuya Ülken şöyle eğilmektedir (1948:102):

“... Şark ve Garbın farkını daha derin bir noktada, sistemli ve sistemsiz düşüncede aramak lazımdır. Şarkın düşüncesi sistemsizdir: orada mefhumlardan kurulan bina, birbirini doğuran fikirler zinciri değildir. Birçok lüzumsuz taşları, yanlış kurulmuş mermerleri vardır. Bazen bütün bir bina küçük bir taş üzerinde durur. Unsurların tutarlılığı ve bağlantısı düşünülmeksizin her tarafı lüzumsuz teferruat içinde boğulmuştur.

Garbın düşüncesi sistemlidir: Orada mefhumlar binası gerçek temeline dayanır. Her yükselen sütun kuvvetini zeminden alır. Her süs bir maksat ve bir lüzum içindir. Orada fikirler birbirine zincir halinde bağlanmış ve hepsi birden en son neticelerine kadar görülmüştür. Felsefe hikmete, hikmet ahlaka ve ahlak siyasete ulaşmıştır. Garbın bu inzibatlı, sistemli tefekkürüdür ki dağınık kuvvetlerin üzerinde medeniyet abidesinin kurulmasını temin eder.

... Garplılaşmak demek kapalı medeniyetten açık medeniyete geçmek demektir. Biz garplıyız veya garplı olacağız demek rasyonel ve üniversal dünya medeniyetine katıldık ve katılacağız demektir.”

“Türkiye'de Çağdaş Düşünce Tarihi” adlı eserinde Batılılaşma konusunu çağdaş kültüre girmek, bağımsız bir çağdaş kültür seviyesine erişmek olarak nitelendiren Ülken, tekniği Batı'dan alma, ama kültürde milli kalma konusunda ise şu görüşleri belirtmektedir (2001:23): 
“Tekniği Batı'dan alalım, fakat ahlakımızda, hukukumuzda şarklı kalalım diyemeyiz. Hatta tekniği, ilmi milletlerarası bir fikir piyasasından alalım, fakat sanatımız, felsefemiz milli olsun hiç diyemeyiz. Böyle bir milletlerarası piyasa yoktur. Ancak çağdaş ve birleşik faaliyetleri olan bir milletler seviyesi vardır. O seviyeye erişmek için sanatta da, hukukta da, ahlakta da, felsefede de, ilimde de yaratıcı olmak gerekir. $\mathrm{Bu}$ değerlerde yaratıcı olmayan bir milletin milletlerarası piyasadan sanat örneklerini, hukuk şekillerini, felsefe eserlerini almasından bir sonuç çıkmaz. Çünkü onları yapan, o üstün kültürün yaratıcılığını ve üreticiliğini sağlayan, dünya görüşü ve zihniyettir. Toptan bir dünya görüşü seviyesine varmadıkça, bu zihniyeti almadıkça çağdaş kültüre girmek mümkün değildir. Bunun için, Yakın ve Orta Doğu'nun birçok modernleşme davranışları, bazıları küçük olan denemelerle ve beceriksizliklerle yüzyıllardan beri sürüp gitmektedir."

Ülken (1948:13;2001:22-23)'in Batılılaşma için yaptığı yorum kısaca, "kapalı medeniyetten açık medeniyete geçmektir." Gelişmek için, batılılaşmak için yaratıcı olmak gerekir. Bu da bütüncül bir dünya görüşüne sahip olmakla mümkündür.

Batılılaşma pek çok yazar tarafindan araştırılmış ve yazılara konu edilmiş bir oluşumdur. Yazarların bakış açılarına göre değişik yorumlar yapılan batılılaşma ve batılılaşma hareketleri, Mümtaz Turhan'a göre; bir "kültür değişmesi" olayıdır. Bernard Lewis'in "Modern Türkiye'nin Doğuşu” ve Niyazi Berkes'in "Türkiye'de Çağdaşlaşma" gibi çalışmalarının da temelini oluşturan Batılılaşma hareketleridir.

Osmanlı İmparatorluğu'nun içinde bulunduğu gerileme ve çöküş dönemi, İmparatorluğun yıllardır görmediği ve önemsemediği Batı dünyasını görmesine ve kendine örnek almasına sebep olmuştur. Bu sebeple ortaya atılan batılilaşma ve çağdaşlaşma, önceleri yenileşme hareketleri ile ülkede zorunlu görülen askeriye ve sonra eğitim... gibi alanlara sokulmuştur. Eğitim alanında yeniliklerin uygulanması ve yeni nesillerin de bu yönelim içine girmeleriyle, bir düşünce akımı halini alan batılılaşma, ülkeyi kurtarmaya yönelik bir girişim olarak düşünülmüştür. Ancak batılılaşma tek başına düşünülmemiş, diğer düşünce akımlarıyla birlikte sentezlenerek uygulanması üzerinde durulmuştur.

Bat1l1laşmak ne kadar mümkündür? ya da Türkler ne kadar batılılaşmıştır? Aslında bu sorular sadece dünün değil, bugünün de merak ettiği ve yanıt aradığı sorular olarak güncelliğini sürdürmektedir.

"Osmanlı Devleti nasıl kurtulur?" sorusuyla ortaya çıkan bir siyasi ideoloji de Osmanlıcılıktır. Kendisinden sonra gelen siyasi akımlara zemin 
oluşturması açısından; Osmanlı siyasi ve düşünce hayatında önemli bir yere sahiptir.

Osmanlıcılık, Osmanlı İmparatorluğu içindeki tüm etnik grupların üzerinde bir "Osmanlıc1lik" duygusu ve bu duyguya paralel olarak bir "Osmanlı Milletini" ortaya çıkararak, Osmanlı Devleti'nin menfaatleri doğrultusunda hareket eden bir düşünce akımıdır. $\mathrm{Bu}$ düşüncenin savunulmaya başlandığı Tanzimat döneminde, İmparatorluk içindeki değişik etnik grupların Batı devletlerinin desteğini alarak bağımsızlığa yöneldikleri göz önüne alınırsa; Osmanlıcılık fikrini ileri süren devlet adamlarının bu yolla iç çekişmeleri yavaşlatmak ve dış baskıları da hafifletmeye çalıştıkları görülecektir.

Osmanlıcılık, Osmanlı İmparatorluğu'nu teşkil eden bütün kavim, cemaat ve milletlerin; din, mezhep, rrk, millet fark1 gözetilmeden; adalet, hürriyet, eşitlik ortamında bir arada yaşamalarını temin etmek isteyen anlayış olarak, Osmanlı Devleti'nin kuruluşundan itibaren fiilli bir şekilde varolmuş ve 19. yüzyılın ikinci yarısından itibaren siyasi bir ideoloji olarak ortaya çıkmıştır. Osmanlı tarihinin üzerinde en fazla tartışılan yönü kuruluşu ve kurucularının etnik kökenidir. Gibbons'a göre, Osmanlı Devleti'ni göçebe Türklerle sonradan Müslümanlığı kabul eden yerli halkın karışımından oluşan yeni bir ırk (Osmanlı 1rk1) kurmuştur. Köprülü’ye göre (1991:5); bir Osmanlı 1rkı, hatta bir Osmanlı kavmi mevcut olmamıştır. Osmanlı ismi, devletin kurucusu olan Osman Bey'den ve hanedanlığın adından gelmiştir. Osmanlı etnik değil, politik bir kavramdır. Osmanlıcılık ise, Osmanlı Devleti sınırları içinde yaşayan herkesi kapsayan bir düşünce akımını oluşturmuştur.

Bir Osmanlı milleti oluşturma politikası, Sultan II. Mahmut'un "Ben tebaamın Müslüman olanını camide, Hıristiyan olanını kilisede, Yahudi olanını havrada fark ederim. Aralarında başka bir gûnâ fark yoktur. Cümlesi hakkındaki muhabbet ve adaletim kavidir ve hepsi gerçek evladımdır." şeklindeki yorumunda açikça ifadesini bulmuştur. 1839'da ilan edilen "Gülhane Hattı Hümayunu"nda bu düşünce, prensip olarak da tespit edilmiştir. Çeşitli dinlere mensup Osmanlılar arasında eşitlik prensibinin oluşturulması yoluna gidilmiş, o dönemin ifadesi ile "toprak kardeşliği" prensibi temel siyaset kuralı yapılmak istenmiştir. İttihat-1 Anasır (Unsurlar Birliği) terimi bu yeni idealin ifadesi olmuş ve çokluğun, çeşitliğin birliğini açıklamakta kullanılmıştır (Tunaya, 2004:26,30,31).

Bir siyasal ideal olarak Osmanlıcılık, 1913'ten sonra zaten çok sınırlı bir kullanıma sahne olmuştur. Önce Balkan Savaşları ve sonrasında I.Dünya Savaşı sırasında Türk milliyetçiliği düşüncesinin ön plana çıktığı, kısmen de bir araç olarak İslâmcılık siyasetinin devreye sokulmaya çalışıldığı 
görülmektedir. I. Dünya Savaşının bitmesiyle Osmanlıcılık düşüncesi de tamamen bitmiştir. Çünkü böyle bir toplumsallaştırma aracılığıyla sistem içinde tutulmaya çalışılan unsurlar artık söz konusu değildir (Hanioğlu, 1985:1393). Ayrıca uzunca bir süredir de, Osmanlıcılık fikrinin olumlu bir yansıması somut olarak görülmemiş, yabancı milletler kendi yollarını çizme eğilimi göstermişlerdir.

Osmanlı İmparatorluğu içinde İslâmcılık hareketi ise, "bir kalkınma ve kurtuluş ideolojisi" olarak Osmanlıcılık hareketinin devamı, Milliyetçilik ve bir ölçüde Türkçülük akımının öncesi şeklinde ele alınabilir.

İslâmcılık akımı, özelliklerini daha çok 19. yüzyılın ortalarında, Osmanlı İmparatorluğu'nun uzak çevresinde ve Hindistan'da şekillenmiş olmasına rağmen, 1870 'lerden itibaren imparatorluğun merkezinde gittikçe güçlenen bir ideolojik davranış kümesine verilen ad olarak açıklanmıştır(Mardin, 1983:1400).

İsmail Kara (1997:16) İslamcıllı̆ı, “XIX-XX. yüzyılda, İslam’1 bir bütün olarak (inanç, ibadet, ahlak, felsefe, siyaset, hukuk, eğitim...) "yeniden" hayata hâkim kılmak ve akılcı bir yöntem ile Müslümanları, İslam dünyasını Batı sömürüsünden, zalim ve müstebit yöneticilerden, esaretten, taklitten, hurafelerden... kurtarmak; medenileştirmek, birleştirmek ve kalkındırmak uğruna yapılan aktivist, modernist ve eklektik yönleri baskın siyasi, fikri ve ilmi çalışmaların, arayışların, teklif ve çözümlerin bütününü içeren bir hareket" olarak tanımlamıştır.

Osmanlı'ya baktığımızda, 1867 yılında Avrupa'ya kaçan ve oradan Osmanlı hükümetine karşı yakın tarihin ilk demokrat-devrimci muhalefetini yürüten aydınlar, geleneksel İslam'ı İslamcıllı̆a dönüştüren ilk kuramcılar olarak karşımıza çıkarlar. Hürriyet isteği ile yola çıkan ve hürriyetin anayasalı-parlamenter bir rejimle sağlanabileceğini savunan bu aydınlar, vardıkları noktada İslam'ı hayata yeniden hâkim kılmak için tekliflerde bulunmuşlardır. Bunlar: Ali Suavi, Namık Kemal, Ziya Paşa... vb. gibi aydınlardır(Türköne, 2003).

Said Halim Paşa, Sebilürreşad Dergisinde yazdığı "İslâmlaşmak" başlıklı yazıda konuya şu şekilde yaklaşır (Said Halim, 1334/1916:256):

“... Bizim için İslamlaşmak demek, İslam ahlakiyatını, içtimaiyatını, siyasiyatını daima zaman ve muhitin ihtiyacına en muvafik bir surette tesir ederek, bunlara tevfik-i hareket etmekten ibarettir.... Kendisinin Müslüman olduğunu söyleyen bir adam, kabul etmiş olduğu din esaslarına uymadıkça, ona göre düşünüp ona göre hareket etmedikçe, yani İslam'ın ahlakiyatına, içtimaiyatına, 
siyasiyatına tamamıyla kendini uydurmadıkça Müslümanım demekle hiçbir şey kazanamaz ve hiçbir mutluluk, huzur elde edemez."

Meşrutiyetten hemen sonra Misır ve Suriye başta olmak üzere Arap İslam dünyasında, Hıristiyan Arapların da etkin bir şekilde rol aldığı Arap milliyetçiliği davası güden ve Osmanlı hilafetine karşı Batılı devletlerle anlaşan birçok grup ve cemiyet ortaya çıkmıştır. Böylece İttihat-1 İslam realitede gerçekleşmesi imkânsız bir duruma gelmiştir. 1910 Arnavut isyanında Arnavut Müslümanların milliyetçi Arnavutları desteklemeleri, ardından Trablusgarp ve Balkan Savaşlarında Türk olmayan Müslüman unsurların Osmanlı Devleti'nin karşısında yerlerini almaları İslamcıları büyük bir sarsıntıya uğratmıştır (Kara, 1997:30).

Osmanlıcılık fikrinin amaçlandığı gibi, Osmanlı Devleti'nin dağılmasına engel olamaması; Aydınları, Müslüman unsurları bir arada tutmayı hedefleyen 'İslam milleti' olarak ifadesini bulan, millet anlayışına yöneltmiştir. Ancak bu süreçte, Müslüman unsurların da Osmanlı Devleti'nden kopmaya başlamalarıyla 'Türk milleti' temelli kimlik oluşturma çalışmaları başlamıştır.

Balkanlarda milliyetçilik hareketlerinin hız kazanması din, dil ve ırk birliğine dayalı Panslavizm politikasının etkisiyle olmuştur. Bu şekilde, Rusların bu bölgelere müdahalesi de kolaylaşmıştır (Kushner, 1979:11). Fransa'nın milliyet esasına dayalı dış politikası ve Avusturya'nın Balkanlara sahip olma isteği milliyetçilik hareketlerini önemli bir ölçüde geliştirmiştir. $\mathrm{Bu}$ arada yapılan reformlar sonucunda da gayrimüslim unsurlar Osmanlı Devleti'nden yavaş yavaş kopmaya başlamışlardır (Kodaman, 1987:111). Balkanlarda ve Anadolu'da milli karakterde çıkan isyanlar sonucu bağımsız devletler belirmiş ve bu devletlerin ortaya çıktığı yerlerde birçok Türk, Anadolu'ya göç etmek zorunda bırakılmıştır. Türklerin içinde bulunduğu bu durum karşısında 'devletin Türk unsuruna ağırlık vermesi' gibi bir görüş, kendisini hissettirmiştir (Kushner, 1979:6).

Türk milliyetçiliğinin doğuşu dil, tarih ve kültür alanındaki araştırmalarla başlamıştır. Dil ve edebiyat alanında başlayan Türkçülük, batıdaki Türkoloji eserlerinden de etkilenerek diğer alanlara yönelmiştir.

II. Meşrutiyet sonrası Aralık 1908 yılında İstanbul'da ilk olarak, "Türk Derneği” adı ile bir dernek kurulmuştur (Üstel, 1997:16-17). Bu dernek Türkçülük akımını destekleyici çalışmalar yürütmüştür. 1911'de Selanik’te çıkmaya başlayan ve edebî bir dergi olan "Genç Kalemler" ise Türkçülük fikrinin daha başarılı ve sistemli bir ifadesi olmuştur. Genç Kalemler dergisinin kurucuları hikaye yazarı Ömer Seyfettin(1884-1920), Ziya 
Gökalp(1876-1924) ve Ali Canip(Yöntem) (1887-1966) gibi yazarlardır (Sadiq, 1972:11).

18 Ağustos 1911 yılında 'Türk Yurdu' cemiyetinin kurulması ile Türkçülügün yeni bir safhası başlamıştır. Cemiyet, 1911 yılı sonlarına doğru kendi adı ile bir dergi çıkarmaya başlamıştır. Akçuraoğlu Yusuf'un idaresinde çıkmaya başlayan Türk Yurdu Dergisi, Türkçülüğe hizmet etmek ve Türklere faydalı olmak amacını gütmüştür. Parola olarak dergi, "Türk milletperverliğì"ni benimsemiştir (Sadiq, 1972:12; Üstel, 1997:42-43).

Türkçülük konusunda bir duayen sayılan ve Osmanlı Türkiyesi’nden uzaklarda Rusya'nın Zoya Köyünde 1904'de "Üç Tarz-1 Siyaset” adlı makaleyi yazan Yusuf Akçura, Türkçülüğün önemli savunucularından olmuştur.

"Üç Tarz-1 Siyaset" adlı yazısının giriş paragrafında Yusuf Akçura, konuya şöyle yaklaşmıştır (Akçura, 1987:19; Yılmaz, 1998:46):

"Osmanlı ülkelerinde, garptan feyz alarak, kuvvet kazanmak ve terakki arzularl uyanall, belli başlı üç siyasi yol tasavvur ve takip edildi sanıyorum: Birincisi, Osmanl hükümetine tabi muhalif milletleri temsil ederek ve birleştirerek bir Osmanlı milleti vücuda getirmek; ikincisi, hilafet hakkının Osmanlı Devleti hükümdarlarında olmasından faydalanarak, bütün İslamlarl söz konusu hükümetin idaresinde siyaseten birleştirmek; üçüncüsü, ırka dayanan siyasi bir Türk milleti teşkil etmektir."

Akçura, yazının ilerleyen kısımlarında Osmanlıcılık, İslâmcılık ve Türkçülük akımlarından ilk ikisinin bir zamanların Osmanlı Devleti'nin genel siyasetine önemli etkisi olduğundan söz ederek, sonuncusunun yani Türkçülügün ise, ancak bazı yazarların yazılarında görüldügünü ifade etmiştir. Akçura bu üç fikirden biri olan Türkçülük düşüncesini, diğerlerine göre daha yapıcı olarak görmektedir. Ona göre, Osmanlıcılık artık terk edilmiştir. 1870'ten sonra İslâmcılık gündemdedir. Türkçülük akımı ise, son zamanlarda ortaya çıkmıştır. Bu makale boyunca aranan cevabın sorusu bellidir, bu soru "Bu devlet nasıl kurtulur?" dur ve Akçura'nın bu soruya yanıtı ise denenmesi gereken 'Türkçülük'tür.

Türkçülük meselesi dünden bugüne devretmiş ve günümüzde de tartışılan ve ön planda tutulan bir gerçek olma savaşını korumaya çalışmaktadır.

Batıcılık, Osmanlıcılık, İslamcılık ve Türkçülük akımları, II. Meşrutiyet döneminde özellikle ilgi çekmişler ve bilinçli olarak savunulmuşlardır. Osmanlı iktidarı üzerinde etkili olmuşlar ve iktidarın ağırlıklı olarak önem 
verdiği akımların izleri sadece siyasi yaşamda değil, sosyal yaşamda da ön plana çıkmıştır. Özellikle eğitim, tarih eğitimi, bu akımları benimseyen kamuoyu oluşturma konusunda yararlı görülmüş ve bilinçli olarak kullanılmıştır. Bu sebeple de, dönem dönem ders programları ve kitaplarında düşünsel değişimler gözlenmiştir.

\section{MEŞRUTIYYT'TEN CUMHURIYET'E TARIH EĞITIMII}

Dönemin bu düşünce yapısı içinde tarih eğitimi ile ilgili çalışmalar, 1869 Maarif-i Umumiye Nizamnamesi ile sistemli bir hal almış ve tarih eğitimine yönelik çalışmalar başlamıştır.

Türkiye'de Tarih derslerinin okullarda yerini alması, I. Meşrutiyet öncesine rastlamaktadır. Saffet Paşanın 1 Eylül 1869 tarihli "Maarifi Umumiye Nizamnamesi"nin altınc1(6) maddesinde Sibyan Mekteplerinde "Muhtasar Tarihi Osmanî" ve "Tarihi Umumi" adları ile iki tarih dersi yer alırken, nizamnamenin yirmi üçüncü(23) maddesinde o zaman dört y1llık olan ve "Rüştiye" diye anılan ortaöğretim kurumlarında "Tarihi Umumî ve Tarihi Osmanı̂" adı ile bir tarih derslerinin bulunmasına karar verilmiştir. Nizamnamenin otuz sekizinci(38) maddesinde "İdadiler"de "Tarih-i Umumi" adı ile bir tarih dersi yer almıştır. Maarifi Umumiye Nizamnamesi"nin kırk altıncı(46) maddesine bakıldığında ise Mekteb-i Sultanilerin Kısm-1 Âli bölümlerinde sadece Edebiyat sınıfında "Tarih" adı ile tek bir dersin bulunduğu açıklanmıştır (M.U.N., 1869:4,9,14,17-18).

1909'lara kadar tarih dersi alanında pek bir gelişme olmamış, öğretmenin inisiyatifinde olan tarih dersi, bir okuma dersi olmaktan öteye geçememiştir.

İttihat ve Terakki'nin iktidarı ele alması ile bu alanda bir canlanma görülmüştür. Ayrıca 1909 yılında, Mülkiye'de öğretmen olan Bakan Nâil Bey'in teklifi üzerine İstanbul Darülmuallimin Müdürlüğüne getirilen ve burasının düzeltilmesi ile görevlendirilen Satı Bey ile tarih öğretimi alanına ağırlık verilmiştir. Bu yılda yayımlanmaya başlayan "Tedrisat-1 İptidaiye Mecmuası", tarih derslerine ait düşünce ve görüşler içermiştir. Bu durum "Klasik Osmanlı Tarih Anlayışı"nın değişmeye başladığının bir göstergesidir. Bu gelişmeyi ders programlarından da izlemek mümkündür (Ergün, 1996:125;Özçelik, 1996:22). Satı Bey yöntem ile ilgili bazı görüşler ileri sürmüştür. "Tedrisatı İptidaiye Mecmuası"nda, "Tarih Tedrisinin Usulü Esasiyesi" başlığını taşıyan makalesi ile tarih kitaplarını ve tarih öğretim yöntemlerini eleştirmiştir. Meşrutiyetin ilanından sonra birçok tarih kitabının yazıldığını ifade eden Satı Bey'in, "Bütün bu eserlere rağmen hala büyük bir eksiklik görülmektedir ki, o da mekteplerde okutulmaya değer ve bilimsel eğitim-öğretimin gereklerine göre hazırlanmış uygun kitapların azlığı, daha 
doğrusu yokluğudur." şeklindeki açıklaması önemlidir. Bu makalede göze çarpan en önemli yeniliklerden biri artık tarih öğretiminin 'milli' olması ve 'milli'lik özelliklerinin ağır basması gerektiği yolundaki görüşlerdir. Gerçekten Satı Bey, "Bütün tarihi konuların milli ve vatani bir bakış açısından gösterilmesini" istemiştir. Aslında Satı Bey'in milliyetçiliği Osmanlıcılık bağlamındadır, ancak bu girişim geleceğe yönelik bir adımdır, Balkanlar'da ve Trablusgarp'ta gelişen olaylar sonrasında milliyetçilik anlayışı Türk milliyetçiliği anlayışına dönüşmüştür. Satı Bey, yöntemle ilgili bu makalesinde bazı açıklamalar da yapmıştır. Ona göre, "ilk olarak tarih derslerinde uzak memleketlere ve eski zamanlara ait olaylar değil, en yakın zamanlara ve en yakın ülkelere ait olaylar anlatılmalıdır. En son seferlerle en yeni savaşlara ilişkin olaylar tarih derslerinin ilk esaslarını teşkil etmelidir" (Sat1, 1327/1909:88-92;Baymur, 1945:12).

1924 yılından itibaren Milli eğitim çalışmaları içinde tarih eğitiminin Cumhuriyetin amaçlarına uygun hale getirilmesi ve daha verimli kılınmas1 noktası tartışılmıştır. Fakat tarih anlayışında belli temel fikirlerin oluşmadığ bu dönemde eğitim vasıtalarının temel unsurlarından biri olan tarih eğitimi ve okul kitapları konusunda henüz köklü bir değişikliğe gidilmemiştir.

\section{TARİH DERS PROGRAMLARINDAKİ DÜŞÜNSEL DEĞIŞSiM}

1908 Devrimi ile özgürlüğe kavuşan yayın faaliyeti, fikir ve edebiyat hayatına büyük bir canlılık getirmiştir. Bu özgür ortam tarih dersinde de kendini göstermiş, daha önce kaldırılan "Genel Uygarlık Tarihi" dersi bu dönemde okullarda yeniden okutulmaya başlanmıştır.

Jön Türklerin, zayıflamış olan Osmanlıcılık düşüncesi, Balkan Harbi’ni noktalayan 1913 yenilgisinin "İttihat-1 Anasır" politikasının iflasını sergilemesinden sonra, tamamen çökmüş ve milli hareket Türkçülük, memleket düşünce yapısına hâkim bir düşünce akımı halini almıştır. $\mathrm{Bu}$ gelişmeler, bilimsel tarihçiliğin yeniden yapılanması ve 1878 öncesinde daha ileri bir düzeye ulaşmasının temelini oluşturmuş̧tur (Berktay, 1983:2459).

Türk Tarihçiliği II. Meşrutiyet dönemi(1908-1918) sonrasında yapılan milli kurtuluş mücadelesi sonucunda Cumhuriyet idaresinin kurulması ile birlikte gelişim göstermiştir. $\mathrm{Bu}$ döneme kadar sürdürülen hanedan tarihçiliği, millilik ve çağdaşlık özelliklerine yönelen yeni tarih anlayışının ortaya çıkmasıyla sona ermiştir. Bu anlayışın oluşmasında Atatürk'ün katkısı büyük olmuş, onun tarihe olan ilgisi bu alandaki gelişmeleri hızlandırmıştır.

Bir bilim olarak eskiçağlardan beri bilinmesine ve üzerinde araştırmalar yapılmasına rağmen, Osmanlı Devleti'nde "Tarih"in resmen bir ders olarak programlarda yer almasının, 1869 Maarif-i Umumiye Nizamnamesi ile 
gerçekleştiğinden daha önce söz edilmiştir. Tarih dersinin bir düzene girmesi ve programlanması açısından Maarif-i Umumiye Nizamnamesi büyük bir öneme sahiptir.

Yapılan incelemelerde görüldüğü kadarıyla tarih dersine yönelik elde edilen ilk program bir kız rüştiyesinin programıdır. 1891 yılında İstanbul'da açılan altı sınıflı "İnas Rüştiyesi”(Kız Rüştiyesi) programında tarih dersi dördüncü sınıfta verilmeye başlanmıştır. Bu okullarda (Ö̈zçelik, 1996:21);

Dördüncü sınıfta :Tarih-i Enbiya (Peygamberler Tarihi)

Beşinci sınıfta :İslam Tarihi

Altıncı sınıfta :Osmanlı Tarihi konularına yer verilmiştir.

Bu programda bulunan "ihtar" bölümünde ise, tarih derslerinin öğretimi ile ilgili olarak öğretmenlere bazı tavsiyelerde bulunulmuştur. Bu tavsiyeleri söyle siralayabiliriz (Mahmut Cevat 1338/1919:390):

1.Tarih dersi hiçbir zaman ezber usulü ile öğretilmeyecek,

2.Öğretmen, öğrencilerin anlayacağı bir şekilde, konuları okutturup, anlatıp, anlattıracak,

3.Öğrencilerin daha iyi anlamalarını tekrarla sağlayacak.

Kız Rüştiyelerine ait tarih dersi incelendiğinde, ders üzerinde İslami düşüncenin ve gelenekselciliğin etkisi görülmektedir. İlk iki sinıfta Peygamberler Tarihi ve İslam Tarihi ile temellenen öğrenciye son sınıfta "Osmanlı Tarihi” dersi verilmektedir. Bu şekilde İslam dinini özümsemiş ve Osmanlı milleti anlayışına sahip, ülkesine bağlı bireyler yetiştirmek amaçlanmıştır. Osmanlı Tarihine önem verilmesi ve okullarda okutulmasında özellikle Yeni Osmanlıların etkisi büyük olmuştur.

Otuz dördüncü Osmanlı Padişahı II. Abdülhamit 1876-1909 yılları arasını kapsayan otuz üç yıllık iktidar döneminde, pek çok konuda olduğu gibi "Tarih" dersi üzerinde de önemli değişiklikler yapılmıştır. II. Abdülhamit döneminde tarih dersinin etkinliği azaltılmaya çalışılmıştır. Bu dönemde Sibyan mekteplerinden tarih dersi kaldırılırken, Rüştiyelerde okutulan tarih konularından Fransız Devrimi ile ilgili olan, milletin krala karşı direnişini konu alan, devrime teșvik eder nitelikteki bölümler çıkarılmıştır (Özçelik, 1996:21-22). Yani ortaokullarda sadece "Osmanlı Tarihi” okutulmuş (Tunçay, 1977:276), bu şekilde toplumun kendi milli uyanışını yaşaması engellenmeye, daha doğru bir ifade ile geciktirilmeye çalışılmıştır. $\mathrm{Bu}$ girişimler yönetimin düşüncesinin tarih dersini ve programlarını doğrudan etkilediğinin bir kanıtı olabilir. Bu dönemde II. 
Abdülhamit'in eğitim uygulamalarında yoğun bir Osmanlıcılık düşüncesinin etkisi görülmüş ve bu düşünce İslamcılıkla birlikte yürütülmüştür.

II. Meşrutiyet döneminde tarih eğitiminin işlevine dönük yeni görüşler ortaya çıkmıştır. Örneğin Kaya’ya göre (2002:44) dönemin en önemli tarih kitabı yazarı Ali Reşat, tarih eğitiminin işlevini, eğitim basamaklarına göre üçe ayırmıştır. Bunlar: İlkokulda pedagojik işlev, ortaokulda siyasi işlev, lisede bilimsel işlevdir.

İlkokulda öğrenci tarih dersi sayesinde hiç görmediği dünyaları hayal ederek kendi dar çevresi dışına çıkabilir; ayrıca neden-sonuç ilişkileri kurmay1 öğrenerek anlama yeteneğini geliştirir. Ortaokulda öğrenci insanlığın nasıl vahşi bir dünyadan uygar bir dünyaya geçtiğini, ortaçağda tiranların elinde tutsak olan halkların nasıl özgürlük ve egemenliklerini kazandıklarını öğrenerek siyasi bilincini geliştirir. Liseye gelen öğrenci için ise tarih, sadece hakikatlere dayanan bir bilimdir. Burada öğrenci sosyolojik olguları, insanlığın devrimlerinin ve ilerlemelerinin nedenlerini öğrenir. Ali Reşat'ta evrensel ilerleme inancı o kadar güçlüdür ki, herhangi bir siyasi güç, hatta herhangi bir ülke lehine yazılan ve öğretilen tarihi reddeder. $\mathrm{Bu}$ nedenle de tarih kitabı yazma konusunda oldukça emek harcamıştır.

23 Temmuz 1908 yılında II. Meşrutiyetin ilanı ile birlikte, II. Abdülhamit döneminde kaldırılan tarih dersleri, programdaki yerini yeniden almaya başlamıştır. Bu dönemde Batı'dan tarih kitapları tercüme edilmiş, meşrutiyetin getirdiği, hürriyet ve özgürlük düşüncesi kendini tarih alanında da göstermiştir. Bu tercüme dalgasıyla Batıcılık akımının etkisi programlara yansımış, özellikle bu temelde dil eğitimine ağırlık verilmeye başlanmıştır. Ancak yabancı dilden çevirisi yapılan tarih ders kitapları, dönemin bazı aydınları tarafından eleştirilmiş̧ir. 1922 Aralık tarihli Büyük Millet Meclisi Maarif Vekâleti'ne İhsan Sungu'nun sunduğu raporda, tarih kitapları hakkında şunlar yazmaktadır (Safran, 2002:826);

“...Mekteplerimizde okutulmak üzere tercüme edilen bir tarih kitabı İslamiyet'te zekatın onda bir olarak hesap edildiğini ve Asuriler hakkında tetkikatta bulunmak için en seri vasıtanın Louvre müzesini ziyaret etmekten ibaret bulunduğunu kaydeden kıraat kitaplarımıza bakılsa bu milletin ruhuna, bu milletin harsina tercüman olmaktan ziyade hepsinden bir tercüme kokusu, bize büsbütün yabancı bir muhitin havayı manevisi hissedilir..."

$\mathrm{Bu}$ açıklamalarla doğrulanacağı gibi çeviri kitaplar, toplumun kültürünü doğru yansıtamamakta ve Avrupa misyonerliği yapmaktadır. İster istemez batı rüzgârları estiren bu kitaplar, Batıcılık akımının da eğitimdeki yansımasını temsil ediyor denilebilir. Hatta tarihe baktığımızda geleceğe yön 
veren aydın kitlesini oluşturan Jön Türklerin batıcılık konusundaki temellerinde, öğrenimleri sırasında gördükleri bu çeviri ders kitaplarının etkileri olduğu yorumunu yapmak yanlış olmayabilir. $\mathrm{Bu}$ nedenle asıl yapılması gereken kendi kültür ve tarihimizi tarafsız olarak yansitan kitapların yazılması ve okutulması olacaktır.

Tarih öğretimi ile ilgili olarak, 1908'den itibaren hazırlanan ve ortaöğretim kurumlarında uygulanan; Lise İkinci Devre Ders Programı(1910), Yedi Yıllık İdadilere ait Ders Programı(1911), İstanbul Mekteb-i Sultaniyesi Ders Programı(1912), Sultanilerin Ders Programı(1913), Sultanilere ait Ders Programı(1914), Mekteb-i Sultaniye Ders Programı(1915), Erkek ve Kiz Liselerine Ait Ders Programı (1922), Sultani (Yeni Medrese) Ders Programı (1922), Lise Müfredat Programı (1924) ve Lise İkinci Devre Ders Programı (1927) araştırma kapsamında incelenmiştir.

Miladi 1910 y1lı ile tarihlendirilen lise ikinci devre ders programı incelendiğinde programın, yirmi bir ana ders ve beş yardımcı dersten oluştuğu görülmektedir. Her alana yönelik derslerin bulunduğu programın ilk sırasında her yıl okutulmak üzere belirlenen 'Ulûm-u Diniye' dersi yer almaktadır. İkinci, üçüncü, dördüncü ve beşinci sıralarda ise, dil eğitimine yönelik olarak 'Arabî', 'Farsî', 'Türkçe' ve 'Fransizca' dersleri bulunmaktadır. $\mathrm{Bu}$ dillerden özellikle 'Fransızca'nın programdaki toplam dokuz saatlik yeri, Batı'ya yönelişin bir etkisi olarak değerlendirilebilir. Dönemin ders kitaplarında da bu etkiler görülmektedir. Örneğin dönemin tarih yazarı Ahmet Refik'e ait altı ciltlik "Büyük Tarih-i Umumi" adlı eserin içeriği Eskiçağların, Avrupa tarihinin, Arap tarihinin kapsamlı bir anlatısından oluşmuştur. Eser içinde Türkler ve geçmişine ilişkin olarak geçen kısım 250 sayfayı geçmemektedir. Eserin altı cildinin üç bin sayfa civarında olduğu düşünülünce, durum daha iyi anlaş1labilir. $\mathrm{Bu}$ dönemde fikri açıdan da bir sentez söz konusudur. Batıcılık ve İslâmcılık sentezi, eskinin devamı ve yenileşmeye duyulan özlem bir birliktelik ile ders programlarında kendini göstermiştir. Osmanlıcılık düşüncesi de kısmen dönemin programında etkisini göstermiştir. Bu etkiyi Ahmet Sâki'ye ait "Muhtasar Osmanlı Tarihi”(1326/1908:63) adlı eserdeki şu ifadesi örnekleyebilir.

"Cahillik lekesini üzerimizden atmağa ne kadar çalışsak devletimiz ve milletimiz o kadar ileriye gidecek ve o vakit hakikat meydana çıkacak: dostlarımız ve düşmanlarımız tasdik edecek ki: “ Osmanlılar büyük bir millettir!'”' 
1910 ders programında "Tarih" dersinin program içinde oldukça ihmal edildiği ve arka plana atıldığı eleştirisini yapmak çok da yanlış olmayacaktır. On dokuzuncu(19.) sırada yer alan tarih dersi, birinci, ikinci ve üçüncü sinıfta sadece birer saat okutulmaktadır. Tarih dersine yardımcı olabilecek derslerde program içinde yer almamıştır(Yücel,1994:147). II. Meşrutiyet döneminin ilk programlarından biri olan 1910 Lise İkinci Devre Ders Programının bu yapısı, "Tarih" dersinin eğitim açısından öneminin anlaşılmadığının göstergesi niteliğindedir. Ancak ilerleyen dönemde tarih dersi hak ettiği ilgiyi bulacak ve programdaki yeri önemsenecek bir duruma gelecektir.

İkinci olarak 1911 tarihli Yedi yıllık idadilere ait ders programı genel olarak incelendiğinde, programın yirmi bir ana ders ve beş yardımcı dersten oluştuğu görülmektedir. Bu programda da ilk sıralarda din bilgisi dersleri bulunmaktadır. Bu dersler ilk dört sene daha ağırlıklı okutulurken, son üç sene haftalık ders süreleri düşmüştür. Buradan dini bilgilerin temelde daha yoğun bir şekilde verildiği ve ikinci devrede ise pekiştirilme yoluna gidildiği yorumunu çıarmak mümkün olabilir. 1911 Programı, 1910 yılına ait lise ikinci devre programıyla karşılaştırıldığında din içerikli dersin 4 saatten 6 saate çıkarıldığı sonucuna varılmaktadır. $\mathrm{Bu}$ da, dinin toplum içindeki öneminin programlardaki bir göstergesi olarak yorumlanabilir. Programda "Tarih" dersinin daha önce bulunduğu on dokuzuncu(19.) siradan, on ikinci(12.) sıraya yükseldiği görülmektedir. Programdaki tarih dersine yönelik bir diğer saptama da, dersin her yıl okutulmak üzere konmasıdır. Tarih dersi; birinci, ikinci, üçüncü, dördüncü, beşinci ve altıncı sınıfta iki saat, yedinci sınıfta ise üç saat olarak belirlenmiştir. Dersin sadece haftada kaç saat olduğu değil, aynı zamanda hangi alana yönelik olarak okutulacağ 1 da programa not olarak eklenmiştir. Buna göre; Birinci sınıfta Tarih-i Enbiya ve Tarih-i İslam, ikinci sınıfta Tarih-i Osmanî, üçüncü, dördüncü, beșinci, altıncı ve yedinci sınıfta ise Tarih-i Umumi alanlarına yönelik tarih ders konularının okutulacağı belirtilmiştir. Yedi yıllık idadilere yönelik bu program, öncesinde incelenen ve sonrasinda incelenecek programlardan bu yönü ile açık bir şekilde ayrılmaktadır. 1911 ders programında dikkati çeken bir diğer konu ise, "Malumat-1 Medeniye" adı ile yurttaşlık bilgisi dersinin programa girmiş olmasıdır. Bu dersin, tarih dersini destekleyici bir ders olması nedeniyle programda yer alması da önemli görülebilir.

Yedi yıllık idadilerde Mekâtib-i İdadiye öğretimi için oluşturulan ve Meclis-i Maarifçe incelenen Tarih dersine yönelik program aşağıda özetlenmiştir. Burada sınıflara yönelik olarak 'Tarih' dersi kendi içinde yıllara göre ayrılmıştır (Tunçay, 1977:277): 
- $\quad$ Birinci Sene : "Tarih-i Enbiya ve Tarih-i İslâm”

- Iİkinci Sene : "Muhtasar Tarih-i Osman̂̂”"

- $\quad$ Üçüncü Sene : "Tarih-i Umumî”

- $\quad$ Dördüncü Sene : "Tarih-i Umumî"

- Beșinci Sene: "Tarih-i Umumî”"

- $\quad$ Altıncı Sene : "Tarih-i Umumî”"

- Yedinci Sene : "Tarih-i Umumî̂"

$\mathrm{Bu}$ programın ve programda yer alan tarih dersinin ayrıntılı içeriği incelendiğinde(1330/1911:5), programda üç düşünce akımının etkisine rastlanır. Bunlar: İslamcılık, Osmanlıc1lık ve Batıc1lıtır.

Tarih dersi konularının sınıflara göre sıralandığı bölüm incelendiğinde, birinci sınıf konularının tamamen "İslam Tarihi"ni içerdiği görülür. Burada bütün peygamberler ve dönemleri ayrıntılı bir şekilde anlatılmıştır. Ayrıca Dört Halife dönemi ve Emeviler dönemi... gibi konulara da yer verilmiştir. Tamamen Arap kültürüne dayalı ve din içerikli bir anlatım gözden kaçmamaktadır. İkinci sınıfta, Osmanlı Devleti'nin kuruluşundan başlanarak padişahlara göre bir dağılımla olayların işlendiği ve II. Abdülhamit devri olaylarına kadar konuların getirildiği gözlenmektedir. Ancak bu sadece bir bölümüdür. İkinci sınıfın diğer bir bölümünde, ilkçağda Mısır, İran, Fenike, Babil, İbrani, Yunan, Roma... gibi medeniyetlere değinilmiş ve özellikle İbraniler bölümünde Yahudilikten de söz edilmiştir. Konuların devamında ortaçağda İslam ve Avrupa tarihine girilmiştir. Kavimler göçü, Müslümanlığın gelişimi, Arap medeniyeti, Avrupa'da derebeylikler, haçlı savaşları, İngiltere, Almanya, İstanbul'un fethi... gibi konular ele alınmıştır. Ayrıca ikinci sınıfta yeniçağ keşifleri, Avrupa'da mezhep savaşları, Fransa, Rusya, Prusya, yakınçağda Avrupa, Fransız Devrimi, Viyana Kongresi, Avrupa devletleri... gibi konular da yer almıştır. Üçüncü sınıfta Tarih-i Umumi başlıklı konular, ilkçağ tarihi ile başlamış ve ortaçağda, yeniçağda, yakınçağda Avrupa tarihi ağırlıklı bir şekilde devam etmiştir. Dördüncü sınıfta başlık yine Tarih-i Umumi'dir. Burada ise, ilk olarak tarihin tanımı, önemi, faydaları... gibi konulara yönelik bilgiler verilmiştir. Devamında ilk çağ uygarlıklarının siyasal ve kültürel özellikleri anlatılmıştır. Ayrıca ortaçağda Avrupa tarihine yönelik bilgiler verilmiştir. Burada ayrıntılı bir Avrupa tarihi anlatımı gözlenmektedir. Beşinci sınıf konuları, Arap tarihi ile başlamış, dört halife devri, haçlı seferleri ve orta çağ medeniyetinin kültürel yapısına ilişkin bilgiler yer almıştır. Altıncı sınıfta konular, Ertuğrul

Gazi'nin devlet kurması ile başlamış ve II. Murat dönemine kadar 
getirilmiştir. Günümüzde "Osmanlı kuruluş dönemi" olarak ifade edilen bir bölüm oluşturulmuştur. Dersin devamında, yeniçağda Avrupa tarihine yönelik konulara yer verilmiştir. Yedinci sınıfta ise, önce Osmanlı'da yeniçağ tarihi, altıncı sınıfta kaldığı yerden devam etmiş, devamında da Avrupa'da ve Osmanlı'da yakınçağ tarihi olayları verilmiştir. Olaylar ele alınırken, çağlara yönelik ayırımlar dikkati çeken özelliklerdir. Ayrıca son dört sınıfta kültüre yönelik bilgilere daha fazla yer verilmiş olması da önemli bir diğer noktayı oluşturmuştur. Programda konuların dağılımı sınıflar arasında eşit olmamış, konu bölümlemede gereksiz ayrıntılara inildiği gözlenmiştir. Türklere ait hiçbir konunun yer almadığı bu tarih programında, birinci yıl verilen "Tarih-i Enbiya ve Tarih-i İslam" konuları ile dini etkinin devam ettiği değerlendirmesine varmak çok yanlış olmayabilir. Bu şekilde ilk yıllarda dini etkinin ağır bastığı konular öğretilmiş, konular daha çok dine yönelik olarak içeriklendirilmiş ve öğrencilerde bir temel oluşturma amacı güdülmüşür. Son sınıflara doğru ise, çizgi değişmiş ve Batı etkisi programda kendini hissettirmiştir. Hatta bu etkinin oldukça abartılı olduğunu söylemenin yanlış olmayacağ 1 kanaatindeyiz. Osmanlı tarihi de az olmakla birlikte unutulmamıştır.

İstanbul Mekteb-i Sultanisi'ne ait 1912 tarihli ders programı incelendiğinde programın on beş(15) dersten oluştuğu görülmektedir. Programa genel itibariyle bakıldığında, haftada altı saatlik süresi ile en ağırlıklı dersin 'Fransızca' olduğu dikkati çekmektedir. Standart olarak her yıl haftada altı saat verilmesi dersin okutulması planlanmıştır. Fransızca dersinin yanı sıra programda dil derslerine önem verilmiş; Arabî, Farisî ve Türkçe de ihmal edilmemiştir. Bu durum ülkenin etnik yapısıyla da yakından ilintilidir. "Ulum-u Diniye" dersi de diğer programlarda da gözlemlendiği gibi yerini korumuştur. Ancak, 1910 ve 1911 programı ile karşılaştırıldığında dersin haftalık süresinin önemli ölçüde azaldığ 1 görülebilir.

Programda, Tarih dersi birinci ve ikinci sınıflarda birer saat; üçüncü, dördüncü, beşinci ve altıncı sınıflarda da ikişer saat olmak üzere haftada toplam on saat olarak belirlenmiştir. Tarih dersi ayrıca 1910 programında on dokuzuncu sırada, 1911 programında on ikinci sırada yer alırken, 1912 programında altıncı sırada yer almıştır. Bu nedenle dersin itibarının arttığını söylemek yanlış olmayabilir. Diğer bir bakışla Tarih dersi her yıl okutulan bir ders görünümünün yanı sıra ağırlığının da giderek arttırıldığı noktası da önemlidir. Ancak Yedi y1llık idadilerdeki gibi her yıl hangi alana yönelik tarih konularının okutulacağı ile ilgili bilgiye program içerisinde yer verilmemiştir. 
Ders programının genel değerlendirilmesi olarak dikkat çekilecek nokta, İslâmcılık ve Batıcılık akımlarının ders programı ve tarih dersi üzerindeki etkisini koruduğudur. Konulardaki yönelimler bu eğilimi göstermektedir. Bu durumun en iyi göstergesi 1920'lerden sonrasina ait Tarih-i Umumi ders kitaplarıdır. İki döneme ait kitaplar karşılaştırıldığında aynı ders içinde dönemlere göre konuların düşünsel bir etki ile farklılaştı̆̆ 1 gözlenmektedir. Örneğin 1910'lu yıllarda yazılan Tarih-i Umumi ders kitaplarında uzun uzadıya Yunanlılar, Romalılar, İranlılar, Araplar, Avrupa devletleri tarihi anlatılırken", 1920'lerden sonrasina ait Tarih-i Umumi ders kitaplarda İslamiyet, Türkler, Osmanlı Devletinin dönemleri, Meşrutiyet,

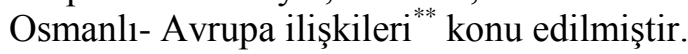

1912 programında, geleneksel çizgi korunmuş ve modernleşme anlamında küçük adımlar atılmaya devam edilmiştir. Tarih dersi ise, her yıl biraz daha önem kazanarak gelişim göstermiştir. Ancak bu gelişim sürekli ileri şeklinde değil, aksaklıklarla birlikte bir ileri bir geri şeklinde seyretmiştir. Örneğin, 1911 tarihli Yedi y1llık idadilere ait programda tarih dersi içinde yıllara göre hangi konuların işleneceğine ilişkin bilgi verilirken, daha sonra hazırlanan 1912 programında bu bilgilere rastlanmamaktadır. Ayrica 1911 programında tarih dersi altıncı sınıfa kadar haftada iki saat, yedinci sınıfta ise üç saat olarak belirlenmişken, 1912 programında ders saatlerinin düşürüldüğü, birinci ve ikinci sınıfta bir saat, devamında ise ikişer saat olarak belirlendiği görülmektedir.

1913 tarihli Sultanilere ait ders programı incelediğinde de "Tarih" dersinin programda altıncı, yedinci, sekizinci ve dokuzuncu sınıflarda ikişer saat olmak üzere toplam sekiz saat olarak verilmesinin planlandığı görülmüş, konulara yönelik olarak ise, ayrıntılı bir açıklamada bulunulmamıştır. Ayrıca dersin sırasında da bir değişme görülerek, 1913 Sultani programında ders üçüncü sıraya çıkmıştır. Bu durum dersin itibarının arttığ 1 düşüncesini destekler niteliktedir. Balkan yenilgisinin de yaşandığı bu dönemde düşünsel çizgi değişimi başlamış, mili birlik anlayışı Osmanlı birliği anlayışının önüne geçmiştir.

Sultanilerin İkinci devresine ait 1914 tarihli ders programında toplam yirmi iki(22) ders bulunmaktadır. 1913 programı ile karşılaştıııldığında derslerin sayısının arttığı ve ağırlaştığı görülmektedir. Bu programdaki en önemli ayrım, sınıfların edebiyat ve fen olmak üzere şubelere ayrılmış olmasıdır. Derslerin haftalık ders saatleri de şubelere göre faklılaşmıştır. Bu programda da aynı düşünsel etkiler söz konusudur.

\footnotetext{
* bkz. Ahmet Refik; Büyük Tarih-i Umumi, 1910: Ali Reşad; Tarih-i Umumi,1916.

** bkz. Ali Reşad; Tarih-i Umumi, 1920: Ali Reşad; Yeni Tarih-i Umumi, 1922.
} 
1914 Sultanilerin ikinci devresine ait programda "Tarih" dersinde, ayrım yapılmaksızın edebiyat sınıflarında da, fen sinıflarında da haftada toplam altışar saat olarak verilmesinin planlandığ 1 görülmektedir. Programda tarih dersinin hangi konu alanlarına yönelik olarak işleneceğine ait bir bilgi bulunmamaktadır. Bu programda, tarih dersinin itibarı açısından da önemli bir gelişme söz konusudur. 1910 ders programında on dokuzuncu sirada yer alan "Tarih" dersi, 1914 programında üçüncü sıraya yükselerek oldukça önemli bir çıkış yakalamıştır. Bu durum ülkedeki siyasi ve düşünsel yapının değişimi ve gelişimi ile bağlantılıdır. Bu dönemde I. Balkan Savaşında alınan yenilgi ile milli bilinçlenme başlamış ve bir ulus olarak birlik içinde kenetlenme düşüncesi ile Türkçülük akımı etkisini arttırmıştır. Zaten tarih literatüründe Türkçülük akımının belirginleşmesinin, 1913 Balkan Savaşları sonrasında olduğu bilinmektedir. Tarih dersinin gelişimi ve ön plana çıkışı da Türkçülük akımının gelişimi ile bir paralellik göstermektedir. Ancak siyasi açıdan etkisini göstermeye başlayan Türkçülük akımının tarih ders programları üzerinde etkisine rastlanamamış, programlarda ve ders kitaplarında İslamcılık ve Batıcılık akımlarının eşgüdümlü etkileri devam etmiştir.

1915 programda ise, tarih dersine yönelik olarak önemli değişikliklerin olduğu görülmektedir. Öncelikle araştırma kapsamında bu aşamaya kadar incelenen programlardakinin aksine sadece bir tarih dersi yerine "Tarih-i Kadim" ve "Tarih" adları ile iki tarih dersinin konduğu görülmüştür. Bu durum, tarih dersi açısından önemli bir gelişmeyi ifade etmektedir. Programda, "Tarih-i Kadim" dersinin üçüncü sırada yer aldığı, "Tarih" dersinin ise onu takip ederek dördüncü sıraya konduğu görülmektedir. "Tarih-i Kadim" adı ile programda yer alan tarih dersi sadece edebiyat şubelerinde okutulmak üzere konmuştur. Bu ders onuncu, on birinci ve on ikinci sınıfların edebiyat şubelerinde birer saat olmak üzere, toplam haftada üç saat olarak belirlenmiştir. Bu derste eskiçağ tarihine ait medeniyetlerle (Mısır, Hint, Asur, Keldani, İran... vs.) ilgili bilgiler verilmiştir. "Tarih" adı ile programda yer alan ikinci tarih dersi ise, her sınıfın her şubesine her yıl ikişer saat olmak üzere haftada toplam altı saat olarak belirlenmiş̧ir. Bu derste ise, yeniçağ, yakınçağ Avrupa ve Osmanlı tarihlerine ait bilgiler karşılaştırmalı olarak işlenmiştir.

1915 tarihli tarih programında II. Meşrutiyetin sonlarına doğru tarih eğitiminin içeriği yeniden değişikliğe uğramıştır. Bu programda göze çarpan ilk değişiklikler, genel olarak tarih ders sayısının artmasıdır. Ayrıca programda yoğun bir şekilde Arap tarihi, İslamiyet konularına yer verildiği, bunların yanı sıra sınırlı olarak Türkler konularının işlendiği görülmüştür (Ali Reşat, 1334/1914). 
1922 y1l ile birlikte devlet yeni bir yapılanma içine girmiştir. Ancak bu girişimler ani olmamış, temkinli ve yavaş bir tavır sergilenmiştir. Miladi 1922 yılı ile tarihlenen, Erkek ve Kız Lise programlarında toplam yirmi bir ders bulunmaktadır. Programdaki sınıflar edebiyat ve fünun olmak üzere iki şubeye ayrılmıştır. Çok yönlü derslerin bulunduğu programda ilk göze çarpan, ilk sırada yer alan "Akaid ve F1kıh" dersidir. Bugünkü karşılı̆̆g ile "İnanç ve Dini Hükümlerin Uygulanışı” olarak çevirebileceğimiz ders her yıl, her şubede birer saat okutulmak üzere programa alınmıştır. Bu dersin yanı sıra "Felsefe" dersinin de program içinde yer aldığı görülmektedir. Felsefe dersinin programda yer alması ve daha önceki döneme göre ağırlığının arttırılmış olması önemli bir gelişme olarak gösterilebilir. $\mathrm{Bu}$ programda "Tarih" dersi dördüncü sırada yer almaktadır. Dersin dokuzuncu sınıfta hem edebiyat hem de fen şubelerinde dört saat olarak okutulması planlanmıştır. Onuncu ve On birinci sınıflarda ise, tarih dersi fen şubelerinde ikişer saat, edebiyat şubelerinde ise dörder saat uygulanmak üzere programda yer almıştır. Bu dönemde savaş sonrası bir değişim söz konusudur. Daha özgürlükçü bir anlayışla tarih dersi de yenilenmiştir. Aynı yıla ait Sultani (Yeni Medrese) ders programında ise toplam yirmi iki ders bulunmaktadır. Programda ilk sırayı "Din Dersleri" adı ile bir din dersi almıştır. Programda İslamcılık akımının etkilerinin yanı sıra zorunlu bir batılılaşma nedeniyle Batıcılık akımının etkileriyle birlikte yer almaktadır. Sultani (Yeni Medrese) ders programında "Tarih" dersi altınc1 sirada yer almaktadır. Tarih dersinin haftalık ders saati ise, birinci sınıfta üç saat, ikinci ve üçüncü sınıfta ikişer saat olarak belirlenmiştir. Programda tarih dersine yardımcı bir başka ders konulmamıştır. Örneğin, önceki programlarda "Malumat-1 Medeniye" dersi programda yer alırken bu programlarda bu ders görülmemektedir. Aynı yılın lise programı ile farklılıklar gösteren sultani programında Felsefe dersi de son sirada ve haftalık ders sayısında bir azalma ile görülmektedir(Yücel,1994:159-160). Burada eski eğitim kurumu ile yeni eğitim kurumu arasındaki fark anlaşılmaktadır. Gerek dersler, gerek derslerin ağırlıklarının değiştiği görülmektedir. Bu durum sultanilerin ne kadar geliştirilmeye çalışılsa da geleneksel anlayışın etkisinden kurtulamadı̆̆ına ve öğretimin birleştirilmesi ilkesinin ne kadar gerekli olduğuna bir kanıt olarak verilebilir.

Tarih dersinde İslami ve milliyetçi konuların ağırlıklı olarak yer alması, özellikle ilkokullarda görülmüştür. Ancak bu dönemde insanların çoğunluğunun ilkokulu okuyabildikleri düşünülürse, bu durumun önemini anlamak daha kolay olabilir. Bu şekilde toplumun kendisini Türk ve Müslüman hissetmesi sağlanmaya çalışılmış, İslâmcılık ve Türkçülük bu dönemde birbirini destekler nitelikte kullanılmıştır. Bunun nedeni 
kazanılması gereken bir savaş olması ve bu savaşın milli ruh ve inanç birliği ile başarılacağının düşünülmesi olabilir. Ancak, I. Dünya Savaşından yenilgiyle çıkılması ve Müslüman kimliğini taşıyan Arapların İngiltere'ye yardım etmesi İslamcılığı geri plana düşürmüş ve milliyetçi uyanış1 perçinlemiş, “Türklük” kimliği ön plana çıkmaya başlamıştır.

1924 Lise ders programı, Cumhuriyet döneminin ilk lise programı olması açısından önemlidir. Bu programda, toplam on sekiz ders bulunmaktadır. Programda öncelikli olarak gözlenen durum, daha önceki programlarda ilk siralarda yer alan din derslerinin bulunmamasidir. Bu dönemden itibaren artık programın ilk sırasında "Türkçe ve Edebiyat" dersi bulunmaktadır. İkinci sırada "Ecnebi Lisanı" dersi yerini almıştır. Cumhuriyetin ilk lise programı olan 1924 programında "Tarih" dersi üçüncü sırada yer almaktadır. Dersin dördüncü ve beşinci sınıfta haftada ikişer saat, altıncı sınıfta da fen şubesinde iki, edebiyat şubesinde dört saat verilmesi planlanmıştır.

Eskiçağ, ortaçağ, yeniçağ ve yakınçağ olarak bölümlere ayrılan tarih dersi konuları, daha çok Avrupa Tarihi ve kısmen Osmanlı Devleti tarihi ağırlıklı olarak sıralanmıştır. Derste özgürlükçü fikirlere de yer verilmesi önemli bir nokta olarak görülebilir. Düşünsel hareketliliğin de konu olarak verildiği programda, Fransız Devrimi, "Büyük İhtilal" başlığı altında ve ayrıntılı bir şekilde verilmiştir. Oysaki II. Abdülhamit döneminde "Fransız Devrimi" gibi özgürlükçü fikirleri vurgulayan, halkın krallara direnişini konu alan bölümler kitaplardan çıkarılmış, bu şekilde konuların toplumu olumsuz etkilemesi engellenmeye çalışılmıştır. Ancak 1924'lere gelindiğinde bu kaygılar bir tarafa bırakılarak, tarihi gerçekler göz önüne serilmiştir. 1924 programı önemli gelişmelerin kaydedildiği bir programdır. $\mathrm{Bu}$ programda eksiklikler olsa da bir başlangıç olması açısından büyük öneme sahiptir.

1924 programının eksikliklerine yönelik olarak bir ek program çıkarılmıştır. Bu zeyl programda da "Tarih" dersinin yeri değişmemiştir ve ders üçüncü sıradaki yerini almıştır. Dersin birinci ve ikinci sınıfta haftada ikişer saat okutulması planlanırken, üçüncü sınıfta şubelere ayrılmamış ve dersin bu sinıfta üçer saat okutulmasına karar verilmiştir. 1924 ilk programında üçüncü sınıf fen ve edebiyat şubelerine ayrılmıştı ve burada tarih dersi fen şubesinde iki, edebiyat şubesinde dört saat olarak belirlenmişti. Zeyl programda bu ayrım sona ermiş ve ders, üçüncü sınıfta üç saat olarak belirlenmiştir. Bu programda dikkati çeken bir diğer ders "Vatani Malumat" dersidir. Bu ders tarih dersine yardımcı bir ders olması açısından önemli görülebilir. 1924 programına yansımada bulunan akım Batıcılık 
olmuştur. Türkçülük akımı ülke politikasına yön veren bir akım olmasına rağmen tarih programına yansıması görülmemiştir (Şengül, 2006:157-159).

1927 y1llına ait Lise İkinci Devre Ders Programında toplam yirmi(20) ders bulunmaktadır. İlk sırada "Türkçe ve Edebiyat" dersi bulunmaktadır. Bu programda da üçüncü sınıf fen ve edebiyat olmak üzere iki şubeye ayrılmıştır. Bu ayrımla, "Türkçe ve Edebiyat", "Tarih", "Felsefe ve İçtimaiyat" dersleri üçüncü sinıfta fen şubesindeki haftalık ders saati kadarını ortak, kalan kısmı ise edebiyat şubesi ayrı işlemektedir.

1927 programında "Tarih" dersi ikinci sırada yer almaktadır. Birinci ve ikinci sınıfta haftada ikişer saat işlenen ders, üçüncü sınıfta fen şubesinde ikişer, edebiyat şubesinde ise, üçer saat işlenmiştir. Ancak üçüncü sınıfta iki şube ikişer saati ortak olarak işlemiş, diğer kalan bir saati edebiyat şubesi ayrı olarak işlemiştir.

Programda, saat azlığı ve kitapların içeriğinin ağır olması üzerinde durularak, Türk tarihi merkezli bir anlayış getirilmiştir. Tarih programında yapılan düzenlemelerin nedenleri ise "Tarih Programındaki Tadilat" başlığı altında şöyle sıralanmıştır (1927:11-12):

“Tarih programı hakkında vaki bulunan şikâyetler şu noktalar etrafinda tespit olunabilir:

1.Mevcut program ekseri sınıflarda saat azlığı dolayısıyla ikmal edilememektedir.

2.Tarih kitapları programın birçok mebahisi sıkıştırmış olması yüzünden çok mufassal olmakta ve talebe bu kitaplar içinde tekamil-i tarihiyi gösterecek vak'aları bulmakta müşkülat çekmekte ve tarih dersine karşı lazım gelen muhabbeti duymamaktadır. Bu şikâyetler etrafında yapılan tedkikat şu neticeyi göstermiştir:

(1) Mevcut müfredat programı Türk Tarihi mihveri etrafında cem' edilmemiştir. Bu yüzden Türk talebesi için bilinmesi zaruri olmayan malumat da programda mühimce bir yer işgal etmektedir.

(2) Mektep kitapları fer'i malumata çok zaman esaslı malumat derecesinde yer vermektedir. Muallimlerin mühim bir kısmı ise kitapta mevcut olan bütün malumatı tamamı tamamına söylemeyi ve talebeden istemeyi vazife bilmekte ve hatta bir kısmı fer'i ve ekseriya talebe için lüzumsuz malumatı kitaba ilaveten söylemekte hatta not edilmekte ve bunun da talebe tarafindan bilinmesini istemektedir.

(3) Muallimlerin ekserisi, tarih tedrisatında talebeyi şahsi ve serbest mesaiye teşvik etmeyi vazifeleri cümlesinden addetmedikleri ve talebenin bir takım malumatı da bu sayede öğreneceklerini düşündükleri için bütün malumatı tedris saati içindeki takrirlere 
sıkıştırmağa çalı̧̧maktadırlar. Bittabi bu yüzden tedris saati kâfi gelmemekte ve program ikmal olunmamaktadır.

Bütün bu noktalar düşünülerek atideki hususata karar verilmiştir:

1.Tarih programı kurun-1 evlanın bir kısmı müstesna olmak üzere Türk tarihi etrafında cem'ine çalışılmak suretiyle tadil olunmuştur.

2.Tadil olunan program mütehassısların mütalâasına göre üçüncü senenin iki saati üçe baliğ edilmek ve iyi bir tedris tarzı takip olunmak şartıyla senelerinde tamamen okutulabilir.

Ancak en mühim şart muallimlerin tarih tedrisatında iyi bir yol takip etmeleridir. Bunun için muallim, elinde mevcut olan kitabı harfi harfine çocuğa takrir etmemelidir. Sınıfta tarihi tekâmüle müessir olan talebeye fikir tarihi verecek olan malumatı bilhassa lisenin ikinci devresine geçmiş olan talebenin kendi kendilerine okuyarak öğrenmelerini temin için talebeye vazifeler vererek şahsi mesainin inkişafına yardım suretiyle çalışmalıdır. Vekâlet, üzerinde tevakuf edilmesi lazım gelen tarihi vakalara ait metin kitap(talebe kitabı) larını hazırlatacaktır. $O$ vakte kadar muallimler, elde mevut olan kitaplardaki esaslı malumatı tefrik ederek tahrir edecekler ve diğer kısımları öğrenmesi için gerek ellerindeki kitaptan ve gerekse mektep kütüphanesindeki asardan talebeyi mütalâaya teşvik eyleyeceklerdir. $\mathrm{Bu}$ şerait altında tebliğ edilen programın muayyen olan saatler zarfinda ikmal edilebileceği mütehassısların mütalâalarından anlaşı1mıştır."

1927 yılına ait tarih dersi programı incelendiğinde programda Türkçülük akımının hâkimiyeti görülmektedir. Bu programla birlikte Türk kültür ve medeniyeti de önemli bir nokta olarak derslerdeki yerini almıştır.

Ziya Gökalp tarafından kaleme alınan "Türk Medeniyeti Tarihi” adlı eser de dönemin liselerinin ikinci devresinde, yani şimdiki lise I,II,III sınıflarında, bir ders kitabı olarak okutulmuştur (Gökalp,1976).

Milli eğitim anlayışı çerçevesinde yapılan çalışmaların somut ilk göstergesi 1927 programında görülmektedir. 1924 yılına kadar programlarda yer alan İslam tarihi ve Arap tarihine yönelik konular 1924 programında tamamen çıkarılmış ve bu program salt Batı medeniyetine ait bilgilerin verildiği bir program halini almıştır. Türkçülük düşüncesinin programlara yansıması ise 1927 programı ile gerçekleşmiştir. Bu programla birlikte Türkçülük hâkim düşünce olmuş ve bu yönde yapılan çalışmaların somut göstergeleri Türk Tarih Tezi düşüncesi ile dünyaya duyurulmuştur.

Araştırmada toplam on ders programı, bu programlarda tarih dersinin yeri ve etkili siyasi düşünce akımları incelenmeye çalışılmıştır. İncelenen 
programlar ve bu programlara etkide bulunan siyasi düşünce akımlarını yansıtan bir tablo oluşturulmuş ve anlatılanları görsel olarak özetlemesi açısından aşağıda sunulmuştur.

Tablo 1. 1908-1930 Yılları Arası Ortaöğretim Ders Programları

\begin{tabular}{|c|c|c|c|c|c|c|c|c|c|c|c|c|}
\hline \multirow{3}{*}{ OKUL ADI } & \multirow{3}{*}{ YIL } & \multirow{3}{*}{$\begin{array}{c}\text { DERS } \\
\text { ADI }\end{array}$} & \multirow{3}{*}{$\begin{array}{c}\text { TARIIH } \\
\text { DERSININ } \\
\text { PROGRAM } \\
\text { ICCíIDEKII } \\
\text { SIRASI }\end{array}$} & \multirow{3}{*}{$\begin{array}{c}\text { ETKIN } \\
\text { SiYASİ } \\
\text { DÜSÜUUNCE } \\
\text { AKIMLARI }\end{array}$} & \multicolumn{6}{|c|}{ SINIF } & \multicolumn{2}{|c|}{ TOPLAM } \\
\hline & & & & & \multicolumn{2}{|c|}{$\mathbf{I}$} & \multicolumn{2}{|c|}{ II } & \multicolumn{2}{|c|}{ III } & & \\
\hline & & & & & 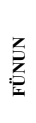 & 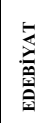 & $\sum_{\text {Z }}^{Z}$ & 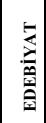 & 㝊 & 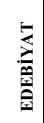 & 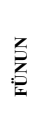 & 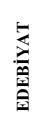 \\
\hline Lise 2. devre & R. $1326-1910$ & Tarih & 19. sira & $\begin{array}{c}\text { İslamcillk } \\
\text { Battclllk } \\
\text { Osmanllık }\end{array}$ & \multicolumn{2}{|c|}{1} & \multicolumn{2}{|c|}{1} & \multicolumn{2}{|c|}{1} & \multicolumn{2}{|r|}{3} \\
\hline 7 Yılllık İdadiler & R.1327-1911 & Tarih & 13. sra & $\begin{array}{c}\text { Islamcillk } \\
\text { Osmanlllkk } \\
\text { Batccllik }\end{array}$ & \multicolumn{2}{|c|}{2} & \multicolumn{2}{|c|}{2} & \multicolumn{2}{|c|}{3} & \multicolumn{2}{|c|}{7} \\
\hline İstanbul Sultaniyesi & R.1328-1912 & Tarih & 6. sira & $\begin{array}{l}\text { İslamcillk } \\
\text { Battccllkk }\end{array}$ & \multicolumn{2}{|c|}{2} & \multicolumn{2}{|c|}{2} & \multicolumn{2}{|c|}{2} & \multicolumn{2}{|r|}{6} \\
\hline Sultaniler & R.1329-1913 & Tarih & 3. sira & $\begin{array}{c}\text { Battcillk } \\
\text { İslamcllkk }\end{array}$ & 2 & 2 & 2 & 2 & 2 & 2 & 6 & 6 \\
\hline Sultaniler & R.1330-1914 & Tarih & 3. sira & $\begin{array}{c}\text { Baticillk } \\
\text { İslamcillk } \\
\end{array}$ & 2 & 2 & 2 & 2 & 2 & 2 & 6 & 6 \\
\hline Mekteb-i Sultaniye* & R.1331-1915 & $\begin{array}{l}\text { Tarih-i } \\
\text { Kadim }\end{array}$ & 3. sira & $\begin{array}{l}\text { Baticllkk } \\
\text { Islamcllık }\end{array}$ & - & 1 & - & 1 & - & 1 & 0 & 3 \\
\hline Mekteb-i Sultaniye* & R.1331-1915 & Tarih & 4. sira & $\begin{array}{c}\text { Baticllik } \\
\text { İslamcllkk }\end{array}$ & 2 & 2 & 2 & 2 & 2 & 2 & 6 & 6 \\
\hline Erkek / Kız Lisesi & R.1338-1922 & Tarih & 4. sra & $\begin{array}{l}\text { Baticillk } \\
\text { İslamcllkk } \\
\text { Türkçülük }\end{array}$ & 4 & 4 & 2 & 4 & 2 & 4 & 8 & 12 \\
\hline $\begin{array}{l}\text { Sultani } \\
\text { (Yeni Medrese) }\end{array}$ & R.1338-1922 & Tarih & 6. sira & Islamclik & \multicolumn{2}{|c|}{$\frac{1}{3}$} & & & \multicolumn{2}{|c|}{$\frac{1}{2}$} & \\
\hline Lise & R.1340-1924 & Tarih & 3. sira & Batıcllik & \multicolumn{2}{|c|}{2} & \multicolumn{2}{|c|}{2} & 2 & 4 & 6 & 8 \\
\hline Lise & R.1343-1927 & Tarih & 2. sira & Türkçülük & \multicolumn{2}{|c|}{2} & \multicolumn{2}{|c|}{2} & 2 & 3 & 6 & 7 \\
\hline
\end{tabular}

* Aynı yıla ait ders programı içinde iki tarih dersi bulunmaktadır.

Yukarıdaki tabloda dönemin ortaöğretim kurumlarında tarih dersinin yeri ve bu programlardaki düşünsel değişim gösterilmeye çalışılmıştır. Tabloda; incelenen okullar, program tarihleri, ele alınan tarih dersinin programda geçen adı, tarih dersinin programda yer aldığı sıra, Programa ve tarih dersine yansımada bulunan siyasi düşünce akımları ve sınıflara göre tarih dersinin haftalık ders süresi ayrı sütunlarda açık bir şekilde gösterilmiştir. Düşünce akımlarını gösteren sütunda programa en çok yansıyan akımdan en az yansıyan akıma doğru bir sıra izlenmiştir. Anlatılan bilgileri somutlaştırması açısından bu tablonun önemli olduğu düşüncesindeyiz.

Ele alınan ilk programdan son programa kadar tablo incelendiğinde tarih dersinin programda öncelik sırası bakımından önemli bir gelişme göstererek on dokuzuncu (19.) siradan ikinci (2.) siralara kadar yükseldiği dikkati çekmektedir. Programlar üzerinde Osmanlıcılık, Batıcılık, İslamcılık ve Türkçülük akımlarının dönem dönem siyasi gelişmelere de paralel olarak etkinliklerini arttırdıkları gözlenmektedir. 
1908 yılından 1930 yılına kadar geçen yirmi iki (22) y1llık zaman zarfında tarih dersinin ve içeriğinin kat ettiği yol oldukça önemlidir.

\section{SONUÇ}

1908-1930 yılları arasında siyasi düşünce akımları ve tarih ders programlarında düşünsel anlamda gerçekleşen değişim araştırılmış ve konuya yönelik değerlendirmeler yapılmıştır. $\mathrm{Bu}$ dönemde ülkede etkili olan siyasi düşünce akımlarının tarih eğitimine yansımalarını göstermek amacıyla yapılan araştırmada toplam on (10) program çerçevesinde bulgulara ulaşılmıştır. Araştırmada öncelikli olarak iki dönem ele alınmıştır. Bunlardan birinci dönem 1908-1918 yıllarını kapsayan Meşrutiyetin ilanından Mondros Mütarekesine kadar olan dönemdir. İkinci dönem ise 1919-1930 yıllarını kapsayan Kurtuluş savaşı ve devrimler dönemidir.

1908-1918 yılları arasinda incelenen programlarda tarih dersinin öneminin azlığına ve geri planda tutulan bir ders olduğuna yönelik gözlemler edinilmiştir. Bu dönemde aşırı bir yoğunluk bulunmaktadır. Öğrencinin aldığ belirlenmiştir. Ayrıca programlarda matematik ve dil derslerinin ağırlığı görülmüştür*. Tarih ders içerikleri de çok ağır ve aşırı ayrıntı bilgilerle doldurulmuş durumdadır. $\mathrm{Bu}$ dönemde incelenen programlarda ve kitaplarda İslamcılık, Batıcılık ve Osmanlıcılık akımlarının etkileri ağırlıklı olarak hissedilmiştir. Dönemin sonuna doğru 1913'lerde Türkçülük akımının ülke politikasındaki etkinliği artmıştır. Ancak yapılan incelemeler siyasi alanda etkin olan Türkçülük akımının eğitim alanına pek yansıtılmadığ 1 yönündedir.

1919-1930 y1lları aras1 okul programları ve tarih programları incelendiğinde ise, derslerin ağırlık olarak azaltıldığ göze çarpar. 19081918 yılları arasında 30'ları bulan ders sayısı, 1919-1930 döneminde 20'lere düşmüştür ${ }^{* *}$. 1930'lara doğru yaklaştıkça temel dersler belirmiş ve bu dersler programdaki yerlerini almışlardır. Bu temel derslerden biri de tarih dersidir. 1908 'den itibaren ortaöğretim programlarındaki yeri incelenen ders 1919-1930 yılları arasında oldukça itibar kazanmış ve ilk incelemelerde görülen on dokuzuncu (19.) siradaki yerini birakarak, ikinci (2.) sıralara kadar gelmeyi başarmıştır. Tarih dersi içeriğinde de değişim görülmüş, İslam dini ve Batı etkisindeki konular, milli kimliğin kazanılmaya başlanmasıyla Türklük, Türk toplumu ve Türk tarihi üzerine kaydırılmıştır. 1919-1930 yılları arasında tarih programlarında etkili olan

\footnotetext{
*bkz. 1910 Lise İkinci Devre Programı, 1911 Yedi Y1llık İdadilere Ait Müfredat Programı. ** bkz. 1924 Lise Müfredat programı, 1927 Lise İkinci Devre Ders Programı.
} 
düşünce akımları ağırlıklı olarak Batıcılık, Türkçülük ve özellikle dönemin ilk yıllarında İslamcılık olmuştur.

Atatürk'ün çağdaş ve milliyetçi anlayışının etkisiyle bu dönemde eğitim, özellikle de tarih eğitimi alanında da çeşitli atılımlar yapılmıştır. Ülke politikası değişim sürecini bu dönemde, inkılâplar sayesinde, daha hızlı bir şekilde yaşamıştır.

Türkçülük akımının tarih eğitimine yansımasını gösteren en önemli girişim kuşkusuz Türk Tarih Tezi çalışmalarıdır. Atatürk'ün direktifleri ile 1929 yılından itibaren Afetinan'ın(1939:244) başkanlığında yürütülen çalışmalar sonucu "Türk Tarihinin Ana Hatları" adı ile bir kitap çıkarılmıştır. Kemalist Tarih Tezinin ilk atılımını temsil eden fakat yeterli ve başarılı görülmediği için okullarda okutulmayan bu kitap, 1931 yılından sonra çıkacak ve okullarda okutulacak tarih kitaplarının (Tarih I, Tarih II, Tarih III, Tarih IV) temelini oluşturmuştur. Böylece hem Türkiye Cumhuriyeti Devleti, hem de tarih dersleri Türkçülük ekseninde şekillenmiştir. Türkçülük akımının eğitimde kendini göstermesi, Tarih dersinin de programlarda statü kazanması ile paralellik göstermiştir. Akımın etkisini arttırması ile ders, programlarda üst sıralara çıkmış ve içeriği ile ilgili önemli değişimler görülmüştür.

Toplumda etkin rol oynayan, dönemin iktidarları tarafından savunulan düşüncelerin, eğitim üzerinde özellikle de tarih eğitimi üzerinde yaptı̆̆ 1 değişime dikkat çekilmek istenen çalışmada; tarih dersinin 1908-1930 dönemi içinde ortaöğretim kurumlarında bir araç olarak kullanıldığ 1 gözlenmiştir. Bir ülkenin hafızasını oluşturan ve geleceğini şekillendiren tarih ve bunun kitlelere açılımını sağlayan tarih dersinin, bir araçtan ziyade bir amaç olarak görülmesi gerektiği ve bu bilinçle gençlerin yetiştirilmesi gerektiği unutulmamalıdır. Tarih dersi ile milli birlik ve kültürün öğrencilere öğretilmesi olabilir bir durumdur ancak bunun tarih programlarının ve kitaplarının devrin politik düşüncesinin etkisinde kalması hatta buna bir de program ve ders kitabı hazırlayıcıların siyasi görüşlerinin yansıması tarih dersini nesnellikten uzaklaştıracak ve araç olma durumunu devam ettirecektir. 


\section{KAYNAKLAR}

Afetinan, A. (1939). Atatürk ve Türk Tarih Tezi. Belleten, Ankara: Türk Tarih Kurumu, Cilt:3, s.243-246.

Ahmet Refik (1327/1909). Büyük Tarih-i Umumi. Cilt:4, İstanbul: Kitabhane-i İslam ve Askeri.

Ahmet Refik (1328/1910). Büyük Tarih-i Umumi. Cilt:1-2-3-5-6, İstanbul: Kitabhane-i İslam ve Askeri.

Ahmet Sâki (1326/1908). Muhtasar Osmanlı Tarihi. Dersaadet: Ahmet Sâki Bey Matbaas1.

Akçay, C. (2006). Türk Eğitim Sistemi. Ankara: Anı Yayıncılık.

Akçura, Y. (1976). Üç Tarz-ı Siyaset. Ankara: Türk Tarih Kurumu.

Akyüz, Y. (2001). Türk Eğitim Tarihi. İstanbul: Alfa Yayınc1lık.

Ali Reşat (1334/1914). Tarih-i Umumi. Cilt:1, İstanbul: Kanaat Kitabhanesi.

Ali Reşat (1339/1920). Tarih-i Umumi. Cilt:4, İstanbul: Kanaat Kitabhanesi.

Ali Reşat (1341/1922). Yeni Tarih-i Umumi. Cilt:2, İstanbul: Kanaat Kitabhanesi.

Ali Reşat (1341/1922). Yeni Tarih-i Umumi. Cilt:3, İstanbul: Kanaat Kitabhanesi.

Baymur, F. (1945). Tarih Öğretimi. Ankara: Maarif Matbaası.

Behar, B. E. (1992). Iktidar ve Tarih. Ankara: Afa yayınları.

Berkes, N. (2003). Türkiye'de Çağdaşlaşma. (Yay.Haz.: A. Kuyaş). İstanbul: Yapı Kredi Yayınları.

Berktay, H. (1983). Tarih Çalışmaları. Cumhuriyet Dönemi Türkiye Ansiklopedisi, İstanbul: İletişim Yayınları, Cilt:9, s.2456-2478.

Doğan, İ. (2005). Modern Toplumda Vatandaşlık, Demokrasi ve İnsan Hakları, Ankara: PegemA Yayınları.

Ergün, M. (1982). Atatürk Devri Türk Eğitimi. Ankara.

Ergün, M. (1996). II. Meşrutiyet Devrinde Eğitim Hareketleri (19081914). Ankara: Ocak Yayınları.

Gökalp, Z. (1976). Türkçülüğün Esasları. (Yay.Haz.: M. Kaplan). İstanbul: Milli Eğitim Bakanlığı. 
Gökalp, Z. (1976). Türk Medeniyeti Tarihi. (Yay.Haz.: İ. Aka-K. Y. Kopraman). İstanbul: Kültür Bakanlığı Yayınları.

Hanioğlu, Ş. (1985). Osmanlıc1lı. Tanzimat'tan Cumhuriyet'e Türkiye Ansiklopedisi, Cilt:5, İstanbul: İletişim Yayınları, s.1389-1393.

İnalcık, H. (1992). Türkiye'nin Modernleşmesi. Atatürkçü Düşünce. Ankara.

Kafadar, O. (1997). Türk Eğitim Düşüncesinde Batılılaşma. İstanbul: Vadi Yayınları.

Kara, İ. (Haz.) (1997). Türkiye'de İslamcılık Düşüncesi 1/2/3 MetinlerKişiler. İstanbul: Kitabevi.

Kaya, H. (2002). Osmanlı'dan Cumhuriyet'e Tarih Dersi Müfredatı. Tarih ve Toplum, İstanbul: İletişim Yayınları, Cilt:16, Sayı:100, s.44-47.

Kodaman, B. (1987). Sultan II. Abdülhamid Devri Doğu Anadolu Politikast. Ankara.

Köprülü, M. F. (1991). Osmanlı Devletinin Kuruluşu. Ankara: Türk Tarih Kurumu.

Kushner, D. (1979). Türk Milliyetçiliğinin Doğuşu(1876-1908). (Çev.: Ş.Türet, R.Ertem, F.Erdem). İstanbul.

Later, J. (1995). Teaching History in The New Europe. Cassell, London.

Lewıs, B. (1998). Modern Türkiye'nin Doğuşu. (Çev.: M. Kıratlı). Ankara: Türk Tarih Kurumu.

Maarif-i Umumiye Nezareti (1869); Maarif-i Umumiye Nizamnamesi. İstanbul: Matbaa-i Âmire.

Maarif-i Umumiye Nezareti (1330/1911). Yedi Yıllık Idadilere Ait Müfredat Programı. İstanbul: Matbaa-i Âmire.

Maarif-i Umumiye Nezareti (1338/1920). Inas Sanayi' Sultanileri Müfredat Ders Programı. İstanbul: Matbaa-i Âmire.

Maarif-i Umumiye Vekâleti (1340/1924). Orta Mekteb ve Lise Müfredat Programlarına Zeyl. İstanbul: Devlet Matbaası.

Maarif-i Umumiye Vekâleti (1340/1924). Liselerin Ikinci Devre Müfredat Programı. İstanbul: Matbaa-i Âmire.

Maarif Vekâleti (1927). Liselerin İkinci Devre Müfredat Programı. İstanbul: Devlet Matbaas1. 
Mahmut C. (1938). Maarif-i Umumiye Nezareti Tarihçe-i Teşkilat ve İcraatı. İstanbul: Matbaa-i Amire.

Mardin, Ş. (1983). İslamc1lık. Cumhuriyet Dönemi Türkiye Ansiklopedisi, İstanbul: İletişim Yayınları, Cilt:7, s.1936-1940.

Mustafa Satı (1327/1909). Tarih Tedrisatının Usul-i Esasları. Tedrisat-l Ítidaiye Mecmuast, Y11:1, Say1:8, s. 88-92.

Mustafa Satı (2002). Eğitim ve Toplumsal Sorunlar Üzerine Konferanslar. (Der.: O. Kafadar- F. Öztürk). Ankara: Türk Tarih Kurumu Basımevi.

Özçelik, İ. (1996). Tarih Öğretiminde Yöntem ve Teknikler. Ankara: Özkan Matbaa.

Özgüldür, $\quad$ Y. (2006). Atatürk ve Çağdaşlaşma. http:www.kho.edu.tr/yayinler/bilimdergisi/doc/2002-2/2_bilder.doc. 28 Şubat.

Prens Sabahattin (1965). Türkiye Nasıl Kurtarılabilir?(1911). (Çev.: M. Sencer). İstanbul: Elif Yayınları.

Sadiq, M. (1972). Türkçülük Cereyanı - Türk Milliyetçiliğinin Eşiğinde (1908-1918). Türk Kültür Araștırmaları, Y11:3,4,5, Say1:5-20, 19661968, Ankara: Türk Kültür Enstitüsü, s.5-20.

Safa, P. (1981). Türk İkklâbına Bakışlar. Ankara: Kültür Bakanlığı Yayinlar1.

Safran, M. (2002). Osmanlı Tarih Öğretimi ve Osmanlı İmajı. XIII. Tarih Kongresi (4-8 Ekim 1999), Cilt: III/II, Ankara.

Said Halim Paşa (1334/1916). İslamlaşmak. Sebilürreşad, Cilt:15, Sayı:278, s.255-257.

Şengül, T. (2005). Geleneksel ve Çağdaş Eğitim Anlayışlarında İlgi ve Disiplin. Millî Eğitim, Bahar 2006, Y11:33, Sayı:166, Ankara: Milli Eğitim Bakanlığı Yayınevi, s.131-136.

Şengül, T. (2006). "Meşrutiyet'ten Cumhuriyet'e Siyasi Fikir Akımlarının Tarih Eğitimine Yansımaları (1908-1931)." Yayımlanmamıș Yüksek Lisans Tezi, Çanakkale Onsekiz Mart Üniversitesi Sosyal Bilimler Enstitüsü, Çanakkale.

Tunaya, T. Z. (2004). Türk Siyasi Hayatında Batılılaşma Hareketleri. İstanbul: İstanbul Bilgi Üniversitesi. 
Tunçay, M. (1977). İlk ve Orta Öğretimde Tarih. Felsefe Kurumu Seminerleri(1975), Ankara: Türk Felsefe Kurumu.

Türköne, M. (2003). Millî Devlet-Laiklik-Demokrasi. Türk Günlüğü. Sayı:75, s.33-51.

Ülken, H. Z. (1948). Millet ve Tarih Şuuru. İstanbul: Pulhan Matbaas1.

Ülken, H. Z. (2001). Türkiye'de Çağdaş Düşünce Tarihi. İstanbul.

Üstel, F. (1997). Türk Ocaklarl (1912-1931): Imparatorluktan Ulus Devlete Türk Milliyetçiliği. İstanbul: İletişim Yayınları.

Y1lmaz, M. (1998). Türk Milliyetçiliğinin Doğuş Dönemi. Türkiye Günlüğü. Sayı:53, Kasım-Aralık, s.41-56.

Yücel, H. Â. (1994). Türkiye'de Orta Öğretim. Ankara: Kültür Bakanlığı Yayınları. 